\title{
THE ROLE OF QUALITY OF HEALTH CARE CONSIDERATIONS IN ANTITRUST ANALYSIS
}

\author{
Thomas E. KaUper*
}

\section{INTRODUCTION}

Proposals for significant reform in the structure and behavior of health care markets, and in the way these markets are regulated, invariably confront claims that the proposed changes will result in a lessening of the quality of care provided. ${ }^{1}$ Demands for broader access to health care services during the 1950's and 1960's, for more effective control of spiraling costs in the 1970's and 1980's, and for some measure of deregulation, have all been met with similar assertions. ${ }^{2}$ Not surprisingly, the intrusion of antitrust and the interjection of a "dose of competition" into health care markets have raised similar issues. ${ }^{3}$ Quality of care is a central concern in virtually any discussion of health care policy; the antitrust policy to be applied in health care markets is no exception.

The focus of this paper is on the appropriate consideration to be given quality-of-care concerns in antitrust cases. In one sense, the focus is narrow, confined to but one aspect of public policy in the health care field. But within the confines of antitrust policy, the issue is pervasive.

For decades, health care services markets have functioned, for better or worse, without the constraints imposed on markets by competitive market

\footnotetext{
Copyright (C) 1989 by Law and Contemporary Problems

* Henry M. Butzel Professor of Law, University of Michigan.

I thank Bruce L. Campbell and Karen S. Calhoun for their valuable research assistance.

1. This is at least in part attributable to the tendency of health care professionals to view themselves as those best qualified to determine appropriate levels of quality of care. Physicians have been, and continue to be, "the leading exponents of quality in medical care." Havighurst \& Blumstein, Coping With Quality/Cost Trade-offs in Medical Care: The Role of PSROs, 70 Nw. U.L. Rev. 6, 25 (1975). Historically, physicians have identified quality with a "free choice" ethic, under which each practiced as an autonomous unit. See generally Weller, "Free Choice" as a Restraint of Trade in American Health Care Delivery and Insurance, 69 Iowa L. Rev. 1351 (1984).

2. Opposition by the American Medical Association ("AMA") to group medical practice, for example, was put partially in quality-of-care terms. See American Medical Ass'n v. United States, 317 U.S. 519 (1943). In recent years, opposition to attempts by insurers and the government to contain health care costs have been attacked on quality-of-care grounds. One of the most recent areas of such conflict is the Medicare prospective payment system. See generally Kinney, Making Hard Choices Under the Medicare Prospective Payment System: One Administrative Model for Allocating Resources Under a Government Health Insurance Program, 19 IND. L. Rev. 1151 (1986).

3. See generally Blumstein \& Sloan, Redefining Government's Role in Health Care: Is a Dose of Competition What the Doctor Should Order?, 34 VAND. L. Rev. 849 (1981).
} 
pressures. Regulation by public authorities has been sporadic and confined to particular segments of these markets and to specific elements of their performance. ${ }^{4}$ Such regulation has often been informal and has generally proceeded without regard to the relationship between public regulation and antitrust. ${ }^{5}$ Self-regulation has been the norm. Actors in these markets long assumed that the antitrust laws were of little or no relevance to their conduct. As a result, health care services markets have been characterized by a variety of structures and actions which in most other industries would raise serious antitrust questions. The introduction of antitrust policy into these markets has therefore resulted in direct challenges to a broad range of conduct within a short period of time. As one plaintiff's antitrust attorney said to me, "Health care is a field ripe for the picking." Given the pervasiveness of selfregulation and other collaborative conduct in these markets, antitrust issues are now also pervasive. In virtually every instance, the concern over quality of care is likely to be raised in justification for the conduct under antitrust attack.

A doctor is denied hospital staff privileges. ${ }^{6}$ Hospitals deny access to midwives or chiropractors, ${ }^{7}$ or enter into exclusive contracts with providers for the performance of specialized services. ${ }^{8}$ Groups of local hospitals, acting

4. Apart from licensing requirements, most governmental economic regulation is targeted at hospitals. Hospital facilities and services have been controlled to some extent through health planning and certificate-of-need programs and through Medicare and Medicaid requirements including, inter alia, the Professional Standards Review Organization ("PSRO"). In some states, hospital rates and/or revenues are directly regulated. These programs are briefly described in Blumstein \& Sloan, supra note 3 , at 866-76.

5. For example, in enacting the National Health Planning and Resources Development Act of 1974, Congress paid little attention to the relationship between antitrust and the health planning it mandated. See National Gerimedical Hosp. v. Blue Cross of Kansas City, 452 U.S. 378 (1981); Hospital Building Co. v. Trustees of the Rex Hosp., 691 F.2d 678 (4th Cir. 1982). State legislation requiring hospitals to engage in quality review has also reflected an inattention to antitrust. As a result, courts have had difficulty in determining whether the state action exemption applies to peerreview activities undertaken pursuant to such legislation. Compare Marrese v. Interqual, Inc., 748 F.2d 373 (7th Cir.), cert. denied, 472 U.S. 1027 (1984), with Tambone v. Memorial Hospital for McHenry County, 635 F. Supp. 508 (N.D. Ill. 1986), and Quinn v. Kent Gen. Hosp., Inc., 617 F. Supp. 1226 (D. Del. 1985). The Supreme Court has held that Oregon legislation did not exempt peer review in that state from antitrust scrutiny, Patrick v. Burget, $108 \mathrm{~S}$. Ct. 1658 (1988), but the decision does not necessarily extend to other states.

6. There are literally scores of these cases. For recent examples, see Goss v. Memorial Hosp. System, 789 F.2d 353 (7th Cir. 1986); Stone v. William Beaumont Hosp., 782 F.2d 609 (6th Cir. 1986). For extended discussions of staff privileges cases see Blumstein \& Sloan, Antitrust and Hospital Peer Review, Law \& Contemp. Probs., Spring 1988, at 7; Kissam, Webber, Bigus \& Holzgraefe, Antitrust and Hospital Privileges: Testing the Conventional Wisdom, 70 Cal.IF. L. Rev. 595 (1982); Note, Denying Hospital Privileges to Non-Physicians: Does Quality of Care Justify a Potential Restraint of Trade?, 19 Ind. L. Rev. 1219 (1986) [hereinafter Denying Hospital Privileges].

7. As to nurse-midwives, see Nurse Midwifery Assocs. v. Hibbett, 549 F. Supp. 1185 (M.D. Tenn. 1982); Comment, Hospital Privileges for Nurse Midwives: An Examination under Antitrust Law, 33 AM. U.L. REv. 959 (1984). With respect to denial of privileges to chiropractors, see Aasum v. Good Samaritan Hosp., 395 F. Supp. 363 (D. Or. 1975), aff'd, 542 F.2d 792 (9th Cir. 1976); Note, Health Professionals' Access to Hospitals: A Retrospective and Prospective Analysis, 34 Vand. L. Rev. 1161, 1191-95 (1981) [hereinafter Health Professionals' Access to Hospitals]. Chiropractors have also attacked the policies of medical societies and accrediting groups which have impaired their access to hospital facilities. See, e.g., Wilk v. American Medical Ass'n, 719 F.2d 207 (7th Cir. 1983), cert. denied, 467 U.S 1210 (1984) (discussed in detail infra text at notes 190-200).

8. See, e.g., Jefferson Parish Hosp. District No. 2 v. Hyde, 466 U.S. 2 (1984); Kuck v. Bensen 647 F. Supp. 743 (D. Me. 1986). 
on their own or through regional planning groups, determine which hospitals will have emergency or burn treatment facilities. ${ }^{9}$ Doctors agree on, or communicate about, the amounts they will accept in reimbursement from insurers, or collaborate to resist other efforts by insurers to reduce costs. ${ }^{10} \mathrm{~A}$ hospital is denied accreditation by an accrediting group which relies in part on judgments by other hospitals. " A physician is denied specialist certification by an organization made up of such specialists. ${ }^{12}$ A hospital (or group of hospitals) opposes the issuance of a certificate of need to a potential competitor. ${ }^{13}$

In each of these cases, serious antitrust issues may be raised. And in each the actors may advance quality-of-care justifications, ranging from the need to keep incompetent physicians from providing care at all to the assertion that greater reimbursement is needed if quality is to be assured. The competitive issues in each case vary, as do the concerns over quality of care. These concerns may be real or imagined, provable or unprovable, and of greater or lesser consequence depending upon the conduct at issue and the magnitude of the restraint involved. But running through this broad range of cases is a single issue which is the central focus of this study. When, if ever, should an antitrust court weigh the impact of conduct on quality of care?

The impact of provider or insurer conduct on the quality of patient care may be interjected into antitrust analysis in one of two ways. First, and most often, the claim may be advanced that a particular restraint is necessary in

9. See Ohio Att'y Gen. Opin. No. 80-059. Horizontal division of markets along product lines is generally a per se violation of section 1 of the Sherman Act. Hartford Empire Co. v. United States, 323 U.S. 386 (1945). Agreements among hospitals with respect to services to be provided that are carried out through regional health planning bodies authorized by federal law thus may violate the antitrust laws unless the federal legislation expressly or impliedly immunizes the conduct from antitrust attack. See National Gerimedical Hosp. and Gerontology Center v. Blue Cross of Kansas City, 452 U.S. 378 (1981); Hospital Building Co. v. Trustees of the Rex Hosp., 691 F.2d 678 (4th Cir. 1982).

10. See, e.g., Arizona v. Maricopa County Medical Soc'y, 457 U.S. 332 (1982) (agreement by physicians on rates to be reimbursed by insurers); Ratino v. Medical Service of the District of Columbia, 718 F.2d 1260 (4th Cir. 1983); Michigan State Medical Soc'y, 101 F.T.C. 191 (1983). See also FTC v. Indiana Fed'n of Dentists, 476 U.S. 447 (1986) (dentists' collective refusal to supply Xrays to insurers); Pennsylvania Dental Ass'n v. Medical Service Ass'n of Pennsylvania, 815 F.2d 270 (3d Cir.) (dentists' collective refusal to refuse participation in Blue Shield plan), cert. denied, $108 \mathrm{~S}$. Ct. 153 (1987). Cf. Superior Court Trial Lawyers Ass'n, Docket No. 9171, 107 F.T.C. 510,3 Trade Reg. Rep. (CCH) I 22,373 (1986), (boycott by lawyers of District of Columbia criminal indigent plan to force increase in reimbursement rates) rev'd and remanded, 856 F.2d 226 (D.C. Cir. 1988), cert. granted, 109 S. Ct. 1741 (1989). Compare United States v. North Dakota Hosp. Ass'n, 640 F. Supp. 1028 (D. N.D. 1986) (agreement by hospitals regarding Medicaid reimbursement rate). See generally Raup, Medicaid Boycolls by Health Care Providers, 69 IowA L. Rev. 1393 (1984).

11. See Sherman College of Straight Chiropractic v. American Chiropractic Ass'n, Inc., 654 F. Supp. 716 (N.D. Ga. 1986), aff'd, 813 F.2d 349 (11th Cir.), cert. denied. 108 S. Ct. 160 (1987). Cf. Marjorie Webster Junior College, Inc. v. Middle States Ass'n of Colleges and Secondary Schools, Inc., 432 F.2d 650 (D.C. Cir.), cert. denied, 400 U.S. 965 (1970), discussed in Havighurst \& King, Private Credentialing of Health Care Personnel: An Antitrust Perspective (Part One), 9 AM. J. L. \& MED. 131, $164-71$ (1984); Kissam, Antitrust Law, the First Amendment, and Professional Self-Regulation of Technical Quality, in Regulating the Professions 143-45 (R. Blair \& S. Rubin eds. 1980).

12. See, e.g., Koefoot v. American College of Surgeons, 652 F. Supp. 882 (N.D. Ill. 1986) (discussed in detail infra note 186).

13. See, e.g., St. Joseph Hosp., Inc. v. Hosp. Corp. of Am., 795 F.2d 948 (1lth Cir. 1986). 
order to assure that the quality of care does not deteriorate. The most common example is the assertion that a physician who has been denied hospital staff privileges is incompetent. Second, conduct might be attacked precisely because it impairs quality of care. Such a case is hard to imagine, but possible. In some circumstances, such conduct may be viewed as a restriction on output. ${ }^{14}$ While the second case is imaginable, most such cases will run afoul of other antitrust doctrines without direct examination of quality-of-care effects. ${ }^{15}$ This paper will focus primarily on the first of these categories.

When, if ever, should there be a quality-of-care "defense"? 16

Part II will develop a general framework for analysis. Part III will examine the decision of the Court of Appeals for the Seventh Circuit in Wilk, a decision that deals more directly than most with quality-of-care issues. Part IV will examine quality-of-care concerns in a variety of other cases.

Before turning to the development of an analytical framework, several factors that have undoubtedly influenced courts in an indirect way should be noted. Seldom dealt with directly, these factors do not fit neatly into conventional doctrine but may have affected outcomes to a greater extent than reliance on existing rules or economic analysis.

First, whatever else may be said about quality of care in a particular setting, the appropriate quality of care is in most instances virtually impossible to define. Even outside the field of health care, product quality is an elusive concept. How, for example, do we as consumers determine the quality of an automobile, or even of a can of tomatoes? In the case of the former, quality may mean a powerful engine or, conversely, high gasoline mileage. An automobile's quality may refer to incidence of repair, or physical appearance. One may value tomatoes because of their color, taste, consistency, or other ingredients. Quality is in the eye of the beholder or, more particularly, the consumer. And, at least given limited resources, consumer decisions about quality involve tradeoffs and consideration of price. As an abstraction, consumers may desire automobiles with mileage ratings in excess of 100 miles per gallon, but they may not value such mileage enough to pay the price such capability would require. Quality without regard to price is a relatively meaningless concept. These ideas are all commonplace and reflect nothing more than the role of the market in determining quality.

Because there is no single perception of quality, in most cases there is no standard by which a court or administrative body can determine that alterations in a product either enhance or degrade its quality. In a few simple cases, such judgments may be possible. If the shelf life of a can of tomatoes is extended from six months to one year by a costless change in the canning

14. See R. Bork, The Antitrust Paradox 35 (1978)

15. Such conduct will generally be accompanied by direct price and output effects. An agreement among competitors to lessen quality by using less costly materials would normally be accompanied by an agreement on the price to be charged for the product.

16. Gordon, Taking the Temperature of the Quality of Care Defense: Is It Critical? (paper presented at program of Antitrust Section, Am. Bar Ass'n, San Francisco, Cal., Aug., 1987). 
process which involves no food additives and leaves the contents unchanged, all may agree that quality is enhanced. But the more complex the product, the more the tradeoffs in other elements of the product the change requires, and the more generalized the claim of improvement, the more difficult the task becomes.

Given these difficulties, is there at least some minimal quality level which can be identified and against which claims of quality deterioration can be measured? The examples given above made no reference to what may seem an obvious quality concern, namely the safety of the product. A can of tomatoes should not poison those who consume it. An automobile should not catch fire each time the ignition key is turned. Under no circumstances would consumers knowingly purchase such a product. Product safety regulation assumes the ability of courts and administrative bodies to make such judgments and to provide regulatory standards, at least in cases where harm may occur before the consumer is aware of the defect. Even these judgments may not be simple. They, too, involve tradeoffs. But judges are accustomed to the resolution of such specific safety issues. They may find the task of evaluating product quality daunting, if not impossible, but once they deal with a specific product defect and a claim of injury resulting from that defect they may find the task much more manageable.

The difficulty of evaluating claims of product quality become even greater in health care markets. ${ }^{17}$ Technology is complex. There are large gaps in knowledge, with resulting scientific disagreement over what even constitutes adequate care. In addition, many believe that everyone is entitled to the same quality of care.

This egalitarian equality of access principle suggests that there is a single quality standard, resulting either from the fact that all consumers desire the best possible care, to the limit of their resources, or from a social policy which demands such uniformity whether consumers desire it or not. ${ }^{18}$ In one sense,

17. See generally Bovbjerg, Competition Versus Regulation in Medical Care: An Overdrawn Dichotomy, 34 VANd. L. Rev. 965, 967-69 (1981); Beales, The Economics of Regulating the Professions, in Reculating The Professions 125, $127-34$ (R. Blair \& S. Rubin eds. 1980); Preston, Competition and Contracting for Health Services in Ohio, 17 TOL. L. REv. 817,819 (1986) ("Basically, no one agrees on what quality means, or how to impose quality standards in our pluralistic and largely unregulated delivery systems."). Apart from purely scientific issues and disagreements, there is little agreement over the relationship between curing and caring. Enthoven, for example, asserts that health care professionals define quality as "the maximum that medical care can do to prolong life or alleviate suffering, costs not considered." A. Enthoven, Health Plan: The Only Practical Solution to the Soaring Costs of Medical Care 50 (1980). But in many cases these ends are inconsistent. See Rosenblatt, Health Care, Markets, and Democratic Values, 34 VAND. L. Rev. 1067, 1090-106 (1981). Because "quality of care" virtually defies definition, the emphasis of both governmental regulation and programs of professional self-regulation has been on the process of evaluating professional performance, rather than on outcomes. See Haug, The Sociological Approach to Self Regulation. in Regulating the Professions 61, 64-66 (R. Blair \& S. Rubin eds. 1980); Havighurst \& Blumstein, supra note 1 , at 25-30.

18. "During the twentieth century, most health care reformers apparently have agreed upon the general idea of universal access-regardless of ability to pay-to a broadly adequate package of socially financed benefits delivered under a single standard of care." Rosenblatt, supra note 17, at 1112. The debate over this egalitarian access principle, which has been ongoing for decades, is beyond the scope of this paper. Suffice it to say that commitment to this ideal has been pervasive, 
the search for a single standard may appear to be easier than in the case where it is acknowledged that quality demanded varies from consumer to consumer. But quality of care is still constrained by the availability of resources, and tradeoffs remain. More important, the egalitarian principle may itself be contested. A judge asked to evaluate the impact of particular conduct on the quality of health care is confronted not only with technological and scientific complexity, but with broad social and political issues as well.

In such circumstances, judges and administrators may be expected to find ways to avoid broad quality-of-care issues except in those cases where quality standards seem obvious and the threat to public safety seems clear (as may be the case, for example, where an obviously incompetent physician is denied hospital staff privileges). They are not likely to seek a role either as the ultimate arbiters of quality, or as Solomons deciding what level of care is appropriate for whom. In antitrust cases, quality-of-care issues may be avoided simply by finding that the conduct at issue has no adverse competitive effects or is not otherwise within the antitrust laws. Some indication that this is occurring is noted below. Avoidance of quality issues may also lead courts in one of two other, but conflicting, directions. Deference may be given to the views of those thought to be more knowledgeable, the very health care professionals whose conduct is at issue. In conventional legal terms, such deference may be reflected in the latitude given to self-regulation by professional groups. ${ }^{19}$ Self-regulation may be perceived as the most appropriate way to assure quality of care, and its preservation becomes an end which antitrust analysis must accommodate. A variety of restraints by professional groups may be upheld with the assertion that self-regulation is desirable, without evaluation of specific quality-of-care claims.

Courts might also avoid such evaluation by eliminating quality-of-care "defenses" (or justifications) altogether, not on the grounds of irrelevance or incompatibility with antitrust doctrine, but on the more practical ground that in most cases such claims are either incapable of proof, or that the proof is likely to be too complex or speculative. Precedent for such an approach may be found in the views of a number of antitrust commentators who would not permit proof of specific efficiencies as a defense in antitrust cases precisely because the identification and quantification of efficiencies is beyond the capability of the legal system. ${ }^{20}$ Similar logic might suggest that quality-ofcare assertions ought not be permitted because in the vast majority of cases

and a major impediment to health care reform. See, e.g., Blumstein \& Sloan, supra note 3, at 859-66. Even if "adequate care" is to be a universal standard, the fundamental problem of defining "adequate care" remains. See Blumstein \& Zubkoff, Perspectives on Government Policy in the Health Sector, 57 Milbank Memorial Fund Q. 395, 411 (1973).

19. See, e.g., Indiana Fed'n of Dentists v. FTC, 745 F.2d 1124, 1144 (7th Cir. 1984), rev'd, 476 U.S. 447 (1986), quoted at note 72 infra; Kaczanowski v. Medical Center Hosp. of Vt., 612 F. Supp. 688, 697 (D. Vt. 1985) (Sherman Act does not "call upon courts to intrude upon a responsibility reserved to medical decision makers").

20. See, e.g., R. BoRk, supra note 14, at 124-29. 
they cannot be proven and/or quantified. In the name of judicial administrability, then, all such claims should be rejected. ${ }^{21}$

Apart from the difficulties of defining quality of care and measuring the impact on quality of particular conduct, judges may also be expected to reflect a degree of skepticism about quality-of-care claims made by health care professionals. Reform of health care structures and markets has been countered time and again by assertions that change will endanger public health and safety through deterioration in the quality and quantity of service. In some cases, the danger has undoubtedly been real. But too often the claims have been speculative or exaggerated and have masked economic objections. ${ }^{22}$ Such assertions have been made too frequently and too speculatively to warrant uncritical acceptance.

Judges and antitrust policy makers may find evaluation of quality-of-care claims difficult. They may, and should, be skeptical about them. And, as we shall see, they may find in established doctrine no clear indication of the relevance of such claims to antitrust analysis. At the same time, however, quality of health care is a critical national issue. Rejection of assertions that a successful antitrust attack on provider conduct will endanger quality of care may place judges in the unenviable position of appearing to disregard the public health and safety in a quest for some ill-defined economic gain to the public through the medium of competition. The dilemma can be avoided by stretching existing rules to conclude that the conduct in question is not covered by the antitrust laws, or, if it is, that no violation has occurred. The resuscitation of the Sherman Act's interstate commerce requirements in hospital staff privileges cases is but one illustration of this phenomenon. ${ }^{23}$ There are others. ${ }^{24}$ But this is not a satisfactory solution. It would not be irrational to conclude that where conduct by health care providers otherwise has significant adverse competitive effects in the market, justifications based on quality-of-care concerns ought not be heard in antitrust cases and in the formulation of antitrust doctrine. Such an approach could be justified because of the difficulties of proof inherent in such quality assertions, the political and social judgments they require judges to make (both in evaluating such claims and balancing those claims against the adverse price and output effects resulting from the restraint), and severe skepticism about them. If the

21. The theory underlying per se rules is similar. Per se rules are based on broad generalizations about the adverse effects of particular conduct in the vast majority of cases. Cases that are not within the generalization are thought to be rare and not worth the time and expense their identification would require. See, e.g., Continental T.V., Inc. v. GTE Sylvania Inc., 433 U.S. 36, 50 n. 16 (1977).

22. See generally Beales, supra note 17, at 134-36; Horowitz, The Economic Foundations of SelfRegulation in the Professions, in Regulating the Professions 3, 7-12 (R. Blair \& S. Rubin eds. 1980). Perhaps the best example was the AMA's effort to curtail group practice in the name of quality. See American Medical Ass'n v. United States, 317 U.S. 519 (1943).

23. For recent examples, see Pariser v. Christian Health Care Systems, Inc., 816 F.2d 1248 (8th Cir. 1987); Sarin v. Samaritan Health Center, 813 F.2d 755 (6th Cir. 1987).

24. Reliance on the state action exemption may in some cases also illustrate the phenomenon. See, e.g., Patrick v. Burget, 108 S. Ct. 1658 (1988); Marrese v. Interqual, Inc., 748 F.2d 373 (7th Cir.), cert. denied, 472 U.S. 1027 (1984). 
competitive process truly threatens quality of care, then intervention through legislative action, where a broad range of economic, social, and political factors can be balanced, is both appropriate and available. Federal antitrust exemptions, or state legislation carefully drawn to extend protection under the "state action" exemption, could provide a vehicle for such intervention. ${ }^{25}$

These considerations suggest that quality-of-care concerns should play a limited role in the antitrust analysis employed in health care cases. They should be taken into account in establishing an analytical framework. But quality of care is not an irrelevant concern in all antitrust cases involving health care. The question to be addressed is when consideration of quality claims is relevant, and whether such claims can be evaluated in a manageable way in particular cases.

II

\section{Quality of Care: A Framework for Analysis}

To define the issues more precisely, consider the following hypothetical case. The National College of Obstetricians certifies obstetricians as specialists, following a series of examinations which it administers. A physician need not have such a certification in order to practice as an obstetrician, but it is a significant credential in the eyes of consumers, hospitals, and insurers. About 60 percent of all obstetricians in the United States have the certification and are members of the College. To remain members in good standing, obstetricians must abide by a number of College rules. Among these is a rule prohibiting any member of the College from performing any obstetrical services in collaboration with midwives and from serving on the staff of any hospital which extends any form of staff privileges to midwives. Based on a careful examination of the market, a court is prepared to conclude that the "anti-midwife" rule significantly restrains competition. The College asserts that the rule is both intended to, and has the effect of, improving the quality of obstetrical services and assuring the health and safety of patients. It is prepared to offer evidence to establish that births assisted by midwives are more dangerous to the mother and the child, that such births carry a higher risk of deformity and brain damage, and so on. The plaintiff has challenged the admissibility of all such evidence, asserting that it is irrelevant in an antitrust case.

The relevance of these quality-of-care facts cannot be determined without a more thorough understanding of the argument being advanced. A qualityof-care "defense" can mean a number of quite different things. First, the College may seek recognition of a limited professional services exemption from the antitrust laws. Adverse competitive effects then would have no

25. For a recent illustration of such an exemption, see Health Care Quality Improvement Act of 1986, Pub. L. 99-660, 100 Stat. 3743,3784 (to be codified at 42 U.S.C. $\$ \$ 1101$ et seq.), discussed extensively in Blumstein \& Sloan, supra note 6, at 39-44, 123-28. 
antitrust consequences. ${ }^{26}$ Second, the College may contend that even if the rule in question has adverse price and output effects, those effects are offset in some way by the social and economic benefits of avoiding deaths and physical harm to the mother and child. Such a justification proceeds on the premise that quality of care is a national goal to be achieved even at the cost of competition. The argument is similar to the suggestion in Chicago Board of Trade $v$. United States ${ }^{27}$ that a restraint might be justified because it tended "to shorten the working day." 28 Third, the College may assert that the quality-ofcare argument goes to the question of adverse competitive effect-more specifically, that quality of care is a relevant competitive factor or that there are no adverse price and output effects because of the preservation of a high quality of care. For example, the College might contend that its certification program provides the public with valuable information about physician qualifications, that the provision of such information corrects the failure of the market to provide adequate information to consumers, and that the midwife rule is necessary in order to assure that the meaning of the certification is not diluted or confused in the minds of the public. ${ }^{29}$ Regardless of whether this argument has merit, it is a quite different argument from either the first or second; it is consistent with the view that antitrust analysis is confined to an examination of price and output effects. Fourth, the College may contend that its rule is saved by a good purpose. In cases where violation may depend on the presence of an anticompetitive intent, a good purpose may negate the presence of the bad. If proof of bad purpose is critical, the evidence on quality of care should be admissible.

The quality-of-care "defense" is thus not a single contention, but a series of distinctly different arguments. Which argument is being advanced is likely to depend on the facts of the particular case before the court. The relevance of the quality impact of a particular restraint may turn on which of these arguments is being presented. But courts confronted with quality-of-care claims have too often failed to understand these differences. The result has been analytical confusion, much of which can be attributed to the Supreme Court.

\section{A. From Goldfarb to Indiana Federation of Dentists}

Prior to the decision in Goldfarb $v$. Virginia State Bar Association, ${ }^{30}$ and its rejection of a categorical "learned professions" exemption from the antitrust laws, relatively few antitrust cases dealt directly with issues of product quality at all. Even fewer dealt with the more precise question of whether conduct

26. This assumes that such an exemption would be absolute; it is hard to imagine a judicially created exemption that would retain an equitable remedy and/or single damage remedy.

27. 246 U.S. 231 (1918)

28. Id. at 241 .

29. The argument assumes that a substantial segment of the public either believes that quality obstetricians do not deal with midwives, or is somehow confused about differences between obstetricians and midwives.

30. 421 U.S. 773 (1975). 
which otherwise was in violation of the antitrust laws could be legally justified upon proof that the restraint enhanced (or prevented deterioration in) product quality. Judicial references to quality usually took the form of recitations that competition assured "the highest quality and the greatest material progress." 31 As far back as Standard Oil Co. v. United States, 32 the Supreme Court observed that "deterioration in quality ... was the inevitable result of the monopolistic control over its production and sale." 33 Quality is therefore dependent upon competition, and impairments of competition are inconsistent with the attainment of product excellence. That a truly anticompetitive restraint might promote product quality seems inconsistent with these simple (and powerful) propositions. Discussions of joint ventures $^{34}$ and product standardization agreements ${ }^{35}$ make occasional references to quality, with little effort at definition or precision. Judicial analysis of quality-of-care justifications, therefore, has tended to focus in precedential terms on recent cases dealing directly with the professions. These decisions, however, have engendered confusion and left a good many questions unanswered.

This confusion began with the Supreme Court's decision in Goldfarb $v$. Virginia State Bar Association, ${ }^{36}$ which found that the use of recommended fee schedules by the Fairfax County (Virginia) Bar Association violated section 1 of the Sherman Act. The Court rejected the contention that the "learned professions" were not engaged in "trade or commerce" and were not therefore covered by the Sherman Act, noting that "the public service aspect of professional practice [is not] controlling in determining whether $\S 1$ includes professions." 37 While Goldfarb dealt specifically with lawyers, it opened the door for the application of the antitrust laws to a wide variety of restraints involving health care markets. But in a now well-known footnote, inserted perhaps out of an abundance of caution, the Court sowed the seeds for the confusion about the relevance of quality-of-care concerns. The footnote states:

The fact that a restraint operates upon a profession as distinguished from a business is, of course, relevant in determining whether that particular restraint violates the Sherman Act. It would be unrealistic to view the practice of professions as interchangeable with other business activities, and automatically apply to the professions antitrust concepts which originated in other areas. The public service aspect, and other features of the professions, may require that a particular practice,

31. Northern Pac. Ry. v. United States, 356 U.S. 1, 4 (1958).

32. 221 U.S. 1 (1911).

33. Id. at 52 .

34. For example, in NCAA v. Board of Regents, 468 U.S. 85, 102 (1984), the Court noted that a number of the NCAA's rules concerning collegiate football were a reasonable and necessary means to assure the "quality" and "integrity" of the product.

35. See, e.g., Structural Laminates, Inc. v. Douglas Fir Plywood Ass'n, 261 F. Supp. 154 (D. Ore. 1966), aff'd per curiam, 399 F.2d 155 (9th Cir. 1968), cert. denied, 393 U.S. 1024 (1969).

36. 421 U.S. 773 (1975).

37. Id. at 787. 
which could properly be viewed as a violation of the Sherman Act in another context, be treated differently . . . ${ }^{38}$

So the antitrust laws apply to the professions, but not quite. This footnote, referred to repeatedly in lower court health care cases, could have any one of several meanings. First, there might be a limited exclusion or exemption for professional activity, in order to preserve its "public service" aspects. ${ }^{39}$ Second, those public service aspects might be thought to outweigh adverse competitive effects. Courts would need to balance price and output effects against social gains. ${ }^{40}$ Third, the first sentence might be taken to mean that markets for professional services are characterized by market forces or failures that differ from those of the other markets. ${ }^{41}$ Analysis of price and output effects must take such differences into account.

Goldfarb was followed by the decision in National Society of Professional Engineers $v$. United States. ${ }^{42}$ The canons of ethics of the Society prohibited competitive bidding. This, according to the government, was tantamount to price-fixing. In defense, the Society asserted that the prohibition was necessary because competitive bidding would result in "inferior work with consequent risk to public safety and health," 43 a contention contrary to the repeated earlier assertions by the Court, noted above, that it is competition which assures quality. The Court's conclusion in Professional Engineers that the Society's ban on competitive bidding could not be justified on quality-ofservice grounds is hardly surprising. The Society was contending that harm to public safety was the necessary result of competition, and that purchasers of engineering services were best served if critical information, the price of such services, was withheld from them for some period of time. Both assertions squarely contradict the assumptions about the competitive model long relied upon in the formulation of antitrust policy. It is the competitive process, and not its absence, which promotes quality. Competition and

38. Id. at 788 n.17. Footnote 17 has been the subject of a great deal of commentary. See, e.g., Leibenluft \& Pollard, Antitrust Scrutiny of the Health Professions: Developing a Framework for Assessing Private Restraints, 34 VAND. L. REv. 927, 934-39 (1981); Elzinga, The Compass of Competition for Professional Services, in Regulating the Professions 107, 116-18 (R. Blair \& S. Rubin eds. 1980).

39. See Kissam, supra note 11, at 148.

40. See Cooper v. Forsyth County Hosp. Auth., Inc., 789 F.2d 278, 282 n.14 (4th Cir. 1986); Boddicker v. Arizona State Dental Ass'n, 549 F.2d 626 (9th Cir.), cert. denied, 434 U.S. 825 (1977); Comment, The Professions and Noncommercial Purposes: Applicability of Per Se Rules Under the Sherman Act, 11 U. MiCH. J.L. REF. 387 (1978).

41. This now appears to be the prevailing interpretation, but only in light of National Soc'y of Professional Eng'rs v. United States, 435 U.S. 679 (1978). See Blumstein \& Sloan, supra note 6; Sullivan \& Wiley, Recent Antitrust Developments: Defining the Scope of Exemptions, Expanding Coverage, and Refining the Rule of Reason, 27 UCLA L. REv. 265, 322-26 (1979). It has been suggested that the differences between professional and other markets noted in Goldfarb make it inappropriate to apply per se rules (or at least the per se rule applicable to boycotts) to professional activity. See, e.g., Kreuzer v. American Academy of Periodontology, 735 F.2d 1479, 1492 (D.C. Cir. 1984); Wilk v. American Medical Ass'n, 719 F.2d 207 (7th Cir. 1983), cert. denied, 467 U.S. 1210 (1984); Kissam, Antitrust Law and Professional Behavior, 62 TEx. L. Rev. 1, 34-36 (1983). But compare Weiss v. York Hosp., 745 F.2d 786 (3d Cir. 1984). Judicial departure from traditional boycott rules in health care cases is likely to gain additional impetus from the decision in FTC v. Indiana Fed'n of Dentists, 476 U.S. 447 (1986). See infra text at note 73.

42.435 U.S. 679 (1978).

43. Id. at 693 . 
therefore quality require knowledge on the part of buyers, who cannot make appropriate choices without it. Professional Engineers makes clear that antitrust rules are directed solely to the competitive effects of the restraint, a significant reformulation of the vague rule of reason standards set forth in Chicago Board of Trade $v$. United States. ${ }^{44}$

On its face, Professional Engineers appears to eliminate quality-of-care "defenses" predicated either on a continuing limited antitrust exemption or on the offsetting of competitive harms against social benefits. Indeed, the Court specifically noted that the "judiciary cannot indirectly protect the public against this harm [defective products that may cause injury] by conferring monopoly privileges on the manufacturers." 45 But the Court went on:

We adhere to the view expressed in Goldfarb that, by their nature, professional services may differ significantly from other business services, and, accordingly, the nature of the competition in such services may vary. Ethical norms may serve to regulate and promote this competition, and thus fall within the Rule of Reason. ${ }^{46}$

While verbally adhering to the Goldfarb footnote, this reservation is more precise. Rather than public service, the touchstone is the nature of the competition. If professional services differ from others, the differences are in the markets themselves. Evaluation of competitive effects must take such differences into account. While the Court does not explain how such markets differ, its discussion of the Engineers' prohibition on competitive bidding is illuminating. The Court recast the justification advanced as an argument that competitive bidding would result in deceptively low bids, noting that an ethical canon targeted only at deception might be legitimate. It was not, however, prepared to equate competition with deception. The Court's willingness to permit self-regulation narrowly focused on deception suggests at least one way in which professional services markets might differ from others-namely, that in such markets consumers are likely to lack information and find it difficult to evaluate the information they do have. Deception might be both more common and more effective in such markets. Widespread deception is an indicator of market failure. Conduct which averts such failure, and does nothing more, is procompetitive. Thus while the Court in Professional Engineers recognizes the Goldfarb reservation, its single-minded emphasis on competitive effects works a substantial reformulation of the Goldfarb footnote. There is no suggestion in Professional Engineers that there is a limited exemption for anticompetitive professional activities. Nor is there any indication that their adverse economic effects are to be balanced against social gains.

Neither Goldfarb nor Professional Engineers deals directly with health care markets. Their references to differences between professional services markets and others, and to the public service aspects of professional life,

44. 246 U.S. 231 (1918). To the extent that Chicago Board of Trade seems to suggest that inquiry under the rule of reason encompasses more than adverse competitive effects, Professional Engineers is a significant reformulation of the standard.

45. 435 U.S. at 695-96.

46. Id. at 696 . 
cannot be taken as identification of structures and market forces peculiar to the provision of health care. In particular, these decisions make no reference to two features of health care markets thought by some to differentiate such markets from virtually all others: the prevalence of third party payment and the central role of providers, rather than consumers, in determining the nature and level of services to be provided. Markets for legal and engineering services are much more normal in these respects. The characteristic common to all professional markets is the difficulty that consumers confront in obtaining and evaluating adequate information upon which to make informed decisions. Some professional self-regulation facilitates the availability of accurate information and the preservation of free choice. ${ }^{47}$ The reservations about the application of the antitrust laws to the professions in Goldfarb and Professional Engineers might well be viewed as suggesting little more than that self-regulation serving this limited purpose should not be impaired by the antitrust laws.

Although Goldfarb and Professional Engineers do not address health care markets directly, they have set the boundaries within which courts have dealt with quality-of-care issues. At the most extreme boundary, Professional Engineers can be read to preclude any direct consideration of quality-of-care effects. ${ }^{48}$ At the other, Goldfarb has seemed to some to suggest that professions enjoy a limited antitrust exemption, or at least that adverse competitive effects must be balanced against non-economic social gains whenever professional activities are found to serve "public service" ends. ${ }^{49}$ While both of these interpretations are overly broad, the area in between these extremes still affords ample ground for disagreement.

The Supreme Court's trilogy of health care antitrust cases following Goldfarb-Arizona v. Maricopa County Medical Society, ${ }^{50}$ Jefferson Parish Hospital District No. 2 v. Hyde, ${ }^{51}$ and FTC v. Indiana Federation of Dentists ${ }^{52}$-leaves little doubt about the general applicability of the antitrust laws to health care activities and considerable doubt about how they are to be applied. While

47. Professional self-regulation may be taken to include both professional standard setting through such activities as accreditation and credentialing programs, and the enforcement of professional and ethical standards through the use of sanctions directed at members of the profession (e.g., sanctions imposed on an attorney who engages in ambulance chasing) or, in some cases, third parties whose conduct is thought inimical to the interests of the profession (e.g., an ethical rule precluding physicians from associating with chiropractors). Standard setting often is procompetitive precisely because it provides information and reduces information search costs. See generally Havighurst \& King, supra note 11, at 173-84; Kissam, Government Policy Toward Medical Accreditation and Certification: The Antitrust Laws and Other Procompetitive Strategies, 1983 WIS. L. REv. I. Professional self-regulation that involves sanctions imposed by the profession itself poses greater competitive risks, but may in some cases also have procompetitive information effects. See, e.g., Kissam, supra note 11 , at 145.

48. See generally 7 P. Areeda, Antitrust Law I 1504 (1986), although Professor Areeda expresses doubt that "the Court meant to go so far as to condemn a restraint that actually saves lives." Id. at 381 .

49. See supra notes 39,40 .

50. 457 U.S. $332(1981)$

51. 466 U.S. 2 (1984).

52. 476 U.S. 447 (1986) 
Goldfarb's reservations about professional services have been expressed in varying ways in each of these cases, the Court has proceeded analytically as though health care markets differ little from others. Only Indiana Federation of Dentists deals directly with quality of care.

The issue in Maricopa was whether conduct characterized by the Court as an agreement among competing physicians to fix the maximum prices to be claimed as full payment from insurers was per se unlawful under section 1 of the Sherman Act. The Court's holding that a per se rule applied did not deal directly with the impact of the challenged conduct on the quality of care provided; the Court simply observed that defendants did not argue that the restraint enhanced quality. But much of the analysis bears on quality issues. The Court reaffirmed the reservation expressed in both Goldfarb and Professional Engineers concerning the application of the antitrust laws to professional conduct. It reverted back to the "public service aspect, and other features of the professions" formulation of Goldfarb, which it quoted directly. ${ }^{53}$ While citing Professional Engineers for the same point, the Court apparently perceived no difference between the two. It then put a further gloss on Goldfarb by finding that because the restraint in question was "not premised on public service or ethical norms" 54 its reservation did not apply. In Professional Engineers, where the Court also spoke of "ethical norms," it suggested that such norms might be lawful where they promote competition. ${ }^{55}$ The meaning of this suggestion is unclear. The implication is that public service and ethical norms are different, and that professional activity in either category might warrant non-conventional analysis. The Court's rather offhand reference to quality of care in this context raises a number of unanswered questions. Is quality relevant only when the conduct in question is a form of public service or in conformity with ethical norms? Is improvement in quality to be equated with public service? Do the Court's observations apply only to the relevance of quality-of-care contentions that would not be relevant under conventional antitrust analysis?

Finally, and most important, the Court showed impatience with contentions that a per se rule should not apply because health care markets possess characteristics not found in other markets. The observation by Justice Powell in dissent that in health care markets the consumer "has no ready way of comparing physicians or of 'shopping' for quality medical services," and his conclusion that the "perfect model" analysis of antitrust therefore provides little guidance, ${ }^{56}$ was dismissed with the assertion that the rationale underlying per se rules is inconsistent with the need to "rejustify" such rules on an industry-by-industry basis. ${ }^{57}$ Where many analysts find a significant difference between health care markets and others-a difference of direct

53. 457 U.S. at 348 .

54. Id. at 349 .

55. 435 U.S. at 699 .

56. 457 U.S. at 366 n.13.

57. Id. at 351 . 
relevance in any evaluation of competitive effects-the Court found none. For the purposes of the per se rule at issue in Maricopa, health care markets were the same as any other.

The Court returned briefly to the quality-of-care issue in Hyde ${ }^{58}$ (though once again the defendant did not formally seek to justify its conduct on quality grounds). The defendant hospital had denied hospital staff privileges to the plaintiff/anesthesiologist because it was party to a contract granting the exclusive right to provide anesthesiological services to another. The Court concluded after an extensive discussion of the standards governing tying agreements that the arrangements did not violate the antitrust laws because the hospital lacked market power. The finding of a lack of market power is of some consequence. Plaintiff contended, and the court of appeals had agreed, that even though defendant hospital's market share was relatively low, there were "imperfections" in the market which indicated that defendant's market power was significantly greater than its market share suggested. The imperfections alleged, not surprisingly, were the prevalence of third party payment, and the unavailability to consumers of adequate information. The Court found such imperfections irrelevant in determining whether patients were "forced" to make purchases they would not otherwise have made. ${ }^{59}$ Thus, in both Maricopa and Hyde, the Court found the market imperfections often relied upon to resist application of the competitive model to health care markets irrelevant to the dispute before it. But its recognition that these imperfections "may generate 'market power' in some abstract sense" 60 is significant. Provider or insurer conduct that does nothing more than reduce or eliminate such imperfections, and thus reduces market power, is procompetitive and should be treated as lawful.

In footnotes, the court made further specific reference to quality of care. In the first, the Court noted that absent evidence that defendant was using market power to force a choice upon consumers, the arrangement was lawful whatever its purpose. ${ }^{61}$ This is an unexceptionable but important point. Conduct without adverse price and output effects need not be justified at all. In the second footnote, the Court declined to consider a series of "procompetitive" justifications, concurring with the lower court that because there was no showing that these effects could not be achieved in a less restrictive way, they could not be used to defend the restraint at issue. ${ }^{62}$ The "less restrictive alternative" analysis is again relatively conventional ${ }^{63}$ and not

\footnotetext{
58. 466 U.S. 2 (1984).

59. Id. at 27 .

60. Id.

61. Id. at 25 n.41.

62. Id. at 25 n.42. In yet a third footnote, the Court observed that while there was little evidence on the quality effect of the exclusive arrangement at issue, "the self-interest of the hospital, as well as the ethical and professional norms under which it operates, presumably protect the quality of anesthesiological services." $I d$. at 31 n.52. While the reference to ethical norms creates some ambiguity, the Court seems to be asserting simply that competitive pressures on the hospital will assure quality.
}

63. See infra text at notes 169-70. 
confined to health care cases, but recognition of the need to evaluate alternatives to the end of quality improvement serves as a significant limitation on the utility of a quality-of-care defense.

Justice O'Connor concurred separately, urging the use of the rule of reason, with its inquiry into both "adverse economic effects, and the potential economic benefits" in tying cases. ${ }^{64}$ She specifically found that the arrangement in question "improves patient care and permits more efficient hospital operation" by assuring twenty-four-hour coverage, standardizing procedures and making more efficient use of equipment, and permitting the hospital "more effectively to monitor the quality" of service. ${ }^{65}$ Her conclusion that "[s]uch an arrangement, that has little anticompetitive effect and achieves substantial benefits in the provision of care to patients, is hardly one that the antitrust law should condemn," 66 may appear to lend support to a broad quality-of-care defense under which gains in quality are offset against adverse price and output effects. This would be a misreading. First, she clearly is speaking of economic benefits, not social benefits that cannot be put in economic terms. Second, these economic benefits are in the form of increased efficiency. Improvement in patient care may occur, but only because resources are more efficiently employed. The assessment of such efficiencies is consistent with the consumer welfare model of antitrust, and involves no peculiar "patient care" defense. ${ }^{67}$

The final case in the trilogy is Indiana Federation of Dentists, 68 where protection of the quality of dental care was the primary justification offered by defendants. At issue was a collective refusal by Indiana dentists, through the Indiana Federation, to supply x-rays along with claim forms to a number of dental care insurers. In order to contain dental care cost, insurers operated under policies limiting payments to the cost of the "least expensive yet adequate treatment," and often insisted that patient x-rays be submitted as part of the claims review process. ${ }^{69}$ After the Indiana Dental Association, the primary professional organization in the state, consented to a Federal Trade Commission order directing the Association to cease efforts to prevent submission of x-rays by member dentists, a group of dentists formed the Federation for the purpose of continuing resistance to insurers' demands. The Federal Trade Commission held that the collective refusal to supply $\mathrm{x}$ rays by the Federation was in violation of section 5 of the Federal Trade Commission Act. ${ }^{70}$ During the FTC proceeding, the Federation attempted to justify its action on quality-of-care grounds, asserting that because $x$-rays alone do not furnish an adequate basis for evaluating dental problems, insurers who rely solely on x-rays would decline to pay for treatment which

64. 466 U.S. at 35.

65. Id. at 43 .

66. Id. at 44 .

67. See infra text at notes 80-83.

68. 476 U.S. 447 (1986).

69. Id. at 449 .

70. 38 Stat. 719, as amended 15 U.S.C. $\$ 45$ (1982 ed. \& Supp. II). 
was in the best interest of the patient. The Commission found no evidence to support this assertion. ${ }^{71}$

On review, the Court of Appeals for the Seventh Circuit found the evidence of anticompetitive effect insufficient to support the Commission's order. The court was not persuaded that the conduct had any impact on competition among dentists. It repeatedly described the Federation's conduct as adherence "to a legal, moral, and ethical policy of quality and proper dental care." 72

The Supreme Court sustained the Commission's order. The Court declined to apply a per se rule, noting, inter alia, that "we have been slow to condemn rules adopted by professional associations as reasonable per se,"73 but found that the Commission's findings of anticompetitive effects were sufficient. The Court observed, referring to Professional Engineers, that withholding or increasing the cost of information desired by consumers in making purchase decisions "may be condemned even absent proof that it resulted in higher prices." 74 Indeed, even if the information were useless in making informed choices, the Federation would not be entitled to make this decision on behalf of its customers.

Having satisfied itself that the Commission could legitimately have found adverse competitive effects, the Court specifically addressed the quality-ofcare justification put forward by the Federation. The court of appeals had equated quality of care with "consumer welfare," employing the phrase used by the Chicago School to describe an antitrust policy focused solely on allocative and productive efficiency. ${ }^{75}$ In sharp contrast, the Supreme Court characterized the proffered justifications as "noneconomic," and rejected them. The Federation's argument was reduced to the proposition that in a free market with access to information consumers deemed relevant, they

71. 476 U.S. at 452 .

72. 745 F.2d 1124 ( 7 th Cir. 1984). The court concluded as follows:

In effect, the Commission's finding of a Federal antitrust violation, based upon the insufficient evidence submitted in this case, is a rubber-stamp approval of the group dental health insurers' practice to formulate a course of dental treatment based solely upon dental $\mathrm{x}$-rays and an insurance claim form, in violation of established, accepted and approved standards of quality dental care. There is no doubt that judicial sanction of such a practice, under the guise of the Federal Trade Commission Act, runs counter to public policy and the very purpose of the Federal antitrust laws as a consumer welfare prescription. Indeed, by preventing dentists from joining together to promote standards of quality dental care that comport with the American Dental Association's code of professional conduct and the Indiana dental code, the Commission, with absolutely no expertise or training in the highly advanced field of dentistry, universally regulates the dental profession and all of its specialties ... to the detriment of consumers. The group dental health care insurers cannot be permitted to forsake standards of quality and proper dental care in an attempt to lower their dental costs, particularly in the instant case where there has been no finding that the review of dental $x$-rays alone, actually reduces dental costs.

Id. at 1144 . The relevance of this passage, which seems directed primarily at the conduct of insurers, is not clear. Nor was it necessary, since the court had already concluded that there was insufficient evidence of anticompetitive effect. But it is highly revealing with respect to the attitude of the court.

73. 476 U.S. at 458 .

74. Id. at 462 .

75. See infra text at note 80 . 
would make "unwise and even dangerous choices;"76 this was precisely the argument rejected in Professional Engineers. There was no reason to believe that the information withheld ( $x$-rays) would be more harmful to consumers in the dental service market than similar information in other markets. True, insurers who make payment decisions are not the ones using the services, but since insurers compete among themselves, they also have incentives to consider the patient's welfare. If their plans do not satisfy dental needs, those purchasing insurance coverage will turn elsewhere. Finally, the Court noted that the Commission had considered the quality-of-care evidence submitted and justifiably found it insufficient. In a footnote which dentists have undoubtedly found particularly disturbing, the Court added, "There is little basis for concluding that, where such a divergence of professional judgment exists, the treatment recommendation made by the patient's dentist should be assumed to be the one that in fact represents the best interests of the patient."77

Indiana Federation of Dentists is an information case, just as was Professional Engineers. In both cases, the quality-of-care argument made was little more than the following: Given the information previously withheld, consumers would make choices reflecting cost/quality tradeoffs that would be harmful to them. Unlike the court of appeals, the Court was simply unprepared to assume that patients and insurers were incapable of making correct decisions. Of some note, the Court's discussion of quality of care makes no mention of Goldfarb's reservations about applying the antitrust laws to professional conduct. The decision gives little comfort to those urging that antitrust analysis in health care markets should take into account a variety of noneconomic factors.

Can the quality-of-care strands taken from Goldfarb through Indiana Federation of Dentists be woven into a coherent whole? The questions are being narrowed, and the nature of inquiry is now more sharply focused. A clear pattern is emerging. First, and most obvious, the Supreme Court has never found professional activity having adverse price and output effects justified by concerns over the quality of service provided. Second, justifications based on the view that competition will necessarily result in quality deterioration are unacceptable. This is the central point in both Professional Engineers and Indiana Federation of Dentists. Third, restraints that take the form of withholding information that consumers might deem relevant to the cost/quality tradeoffs involved in purchase decisions are both anticompetitive and unjustified, with the exception, perhaps, of information that is in most cases likely to deceive, or that is too easily abused in a deceitful way. Even in the latter case, however, the restraint may be upheld only if there is no less

76. 476 U.S. at 463.

77. Id. at 464 n.4. Professor Kissam has observed, "[ $t]$ he Court also has become increasingly skeptical about the scope and validity of professional claims." Kissam, supra note 41, at 19. Nowhere is this more apparent than in this footnote, which goes counter to the oft-repeated view of health care providers that in the fact of uncertainty "the doctor knows best." There is no deference to professional judgment here. 
restrictive means available for dealing effectively with the problem of deception. Conversely, where consumers lack the information upon which to make such judgments, a restraint that enhances the availability of information, and thus reduces an element of "market imperfection" (the description in Hyde), might to that extent be viewed as procompetitive.

The Court has been less tolerant of other market failure arguments. While the prevalence of third party payment and the role of providers in determining the level and quality of service have been noted, the Court has not found such failure or imperfections relevant in the cases before it. In both Maricopa and Hyde, arguments based on these factors were rejected. The Court in this sense has treated health care markets like most others.

These conclusions are consistent with the basic premise that quality is enhanced through the competitive process, where consumers make quality/cost tradeoffs through informed choice among a variety of goods and services. Conduct that simply eliminates market failures, or that through the creation of efficiencies results in delivering the same services at a lower cost, is procompetitive. The Court's repeated assertions that professional conduct, and conduct in health care markets in particular, should be evaluated under standards that differ significantly from those more generally applied has created confusion. The Court's reservations about professional activity have not been expressed in a consistent manner. As already noted, Goldfarb and Maricopa can be read to suggest that some limited professional exemption may exist, or that courts should somehow balance social gains against economic harms. Conversely, Professional Engineers suggests only that the nature of competition in professional services markets may be different, and thus requires more careful analysis. Its reference to ethical norms is in the context of promoting competition, and indicates only that norms having such an effect might not be governed by per se rules. These imprecise references to public service and ethical norms have allowed lower courts to treat quality-of-care issues in a variety of inconsistent ways, and in a manner reflecting biases more than consistent principles of antitrust analysis. Focus on public service and ethical norms diverts attention from economic analysis. It leads to an emphasis on the tradition of self-regulation, without regard to the ends such self-regulation should serve, and thus becomes a vehicle for maintaining the status quo.

Despite the confusion caused by the Goldfarb footnote and its progeny, the Court in its health care cases is generally moving in a direction in which quality of care is simply a factor in the analysis of adverse competitive effects. Here, as elsewhere, the Court has applied a consumer welfare standard focused directly on price and output effects. ${ }^{78}$ Only the reservations about

78. Beginning with its decision in Continental T.V., Inc. v. GTE Sylvania Inc.. 4.3.3 11.5 . :36; (1977), the Supreme Court has moved steadily in the direction of an antitrust policy bassed upou

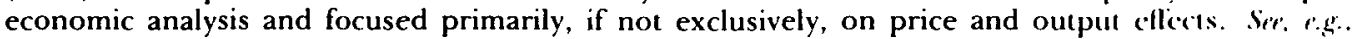
Matsushita Elec. Indus. Co. v. Zenith Radio Corp., 475 U.S. 574 (1986); National Collegiate Athletic Ass'n v. Board of Regents of Univ. of Okla., 468 U.S. 85 (1984); Broadcast Music, Inc, v. Columbia 
professional activity expressed in Goldfarb are inconsistent with this view. Market structures and forces may be different in health care markets, and these differences may be relevant in evaluating the price and output effects of particular conduct, but the antitrust principles applied remain the same. The critical questions for the future, then, are whether and how quality of care is relevant in the economic analysis of restraints in markets for professional services, and whether antitrust analysis should give weight to quality-of-care factors beyond their relevance in such economic terms.

\section{B. The Appropriate Analysis of the Quality-of-Care Defense}

The preoccupation with quality of care in the antitrust analysis of conduct in health care markets may leave the impression that the quality of products and services has no relevance in antitrust analysis generally. This is not the case. It would be more accurate to say that antitrust recognizes no single quality defense. Quality has been, and is, of direct relevance in a variety of ways. It is the thesis of this study that no special consideration of quality beyond that which antitrust currently contemplates is either necessary or appropriate; contemporary antitrust standards should be applied without special treatment for professionals in general and health care professionals in particular. This is not to say that concerns over quality of care or, more likely, equal access to adequate care, could not cause policy makers to modify competitive outcomes through enactment of federal antitrust exemptions or state legislation sufficient to invoke the state action exemption. However, the political, social; and economic policy judgments such action requires are more appropriate for legislatures than courts. ${ }^{79}$ Tort rules governing malpractice and other quality abuses also continue to provide quality-of-care incentives. There is no quality-of-care defense in antitrust cases; nor should there be.

\section{Quality of Care As a Factor in Consumer Welfare Analysis.}

a. The general approach. If professional activity receives no special dispensation, how is quality of care relevant in antitrust cases? I assume initially that antitrust is focused solely on allocative and productive efficiency, and that a variety of other economic, social, and political concerns (ranging from income distribution to the preservation of small business) are not relevant. $^{80}$ Antitrust intervention should occur only when conduct raises price and restricts output, or is likely to do so. ${ }^{81}$ The questions addressed are economic, and economic analysis governs outcomes. Whether antitrust is, or

Broadcasting Sys., 441 U.S. 1 (1979). See generally Gerhart, The Supreme Court and Antitrust Analysis: The (Near) Triumph of the Chicago School, 1982 Sup. CT. REv. 319.

79. See R. BоRK, supra note 14 , at $82-84$.

80. This is the "consumer welfare" standard of the so-called Chicago School, a view which presently dominates in antitrust policy making. For general expressions of this view, see R. Posner, Antitrust Law: An Economic Perspective 8-22 (1976); R. Bork, supra note 14, at 51-115; Gerhard, supra note 78, at 320-22. See generally Posner, The Chicago School of Antitrust Analysis, 127 U. PA. L. REv. 925 (1979).

81. See R. BORK, supra note 14 , at $116-33$. 
should be, so limited in its outlook is a hotly contested proposition. ${ }^{82}$ But prevailing antitrust standards are largely in accord with this "consumer welfare" model. ${ }^{83}$ The discussion that follows begins with consideration of price and output effects.

Quality as such is an indeterminate fact, in most cases. Consumer perceptions of quality vary, as do the quality/cost tradeoffs consumers make every day. This is true in most health care markets, even though some may aspire to a universal standard of best or adequate care. Even if such a standard existed, there would be little agreement over whether it has been satisfied. Medical procedures are the subject of considerable professional disagreement. Scientific knowledge may well be inconclusive. In many cases, even the minimum safety standards are elusive. A given treatment may be safe for some, and not for others. Even a very high risk procedure-a procedure most would deem unsafe-may represent the best quality to one who is terminally ill. The legal standard employed in malpractice and other tort liability cases, the duty to exercise reasonable care, reflects this difficulty of absolute definition, but is inadequate as a standard against which to measure conduct that allegedly violates the antitrust laws. The definition and identification of quality is surely no more possible in health care markets than in others. ${ }^{84}$

Quality, then, is not an absolute. It is the result of a competitive process in which consumers have choices, and which provides incentives to producers to improve goods and services in ways that make them more saleable. Quality is a result of the competitive process. This has been a central point in antitrust analysis for decades. ${ }^{85}$ Economic analysis starts with the same basic premise. ${ }^{86}$ There is in most cases a fundamental contradiction in the argument that quality can be enhanced through restraints among producers (providers) that significantly restrain the competitive process and result in adverse price and output effects.

Several caveats to these broad propositions are necessary. In theory, an agreement among providers to improve quality without employment of any additional resources is an increase in output, assuming that the agreement

82. I have described the debate over antitrust's goals elsewhere. See Kauper, The Goals of United States Antitrust Policy-the Current Debate, in 136 Zeitschrift für DIE GeSamte STAatswissensChaft 408 (1980) (article in English). See also Kauper, Comment: The Sullivan Approach to Horizontal Restraints, 75 Calif. L. Rev. 893, 896-901 (1987). The debate over goals continues. Compare Easterbrook, Comparative Advantage and Antitrust Law, 75 Calif L. Rev. 983 (1987); Easterbrook, Workable Antitrust Policy, 84 Mich. L. Rev. 1696, 1700-02 (1986), and Baxter, Responding to the Reaction: The Draftsman's View, 71 Calif. L. Rev. 618, $619-21$ (1983), with Sullivan, Anticipating Antitrust's Centennial: The Viability of the Current Law on Horizonlal Restraints, 75 CALIF. L. Rev. 835, 838-41 (1987); Fox, Consumer Beware Chicago, 84 Mich. L. Rev. 1714, $1718-19$ (1986); Fox, The Modernization of Antitrust: A New Equilibrium,

66 Cornell L. Rev. 1140 , $1146-55$ (1981).

83. See supra note 78 .

84. At a bare minimum, quality of medical care is no easier to define than quality with respect to any other service or product. Compare Beales, supra note 17, at 126-32, with Elzinga, supra note 38, at 108-09.

85. See supra text at notes $31-33$.

86. For a strong statement of the classic view, see Kartell v. Blue Shield of Mass., Inc., 749 F.2d 922, (1st Cir. 1984), cert. denied, 471 U.S. 1029 (1985). 
brings no increase in price. Similarly, an agreement that results in a lowering of quality without a lowering of prices or change in the resources employed may be characterized as a restriction of output, and should be condemned as such. ${ }^{87}$ This has been implicitly recognized in antitrust cases in which defendants have contended that they should be absolved because their conduct did not raise prices, restrict output, or lower the quality of the product. ${ }^{88}$ But these theoretical principles are of little utility in antitrust analysis. Quality changes cannot normally be measured. It is unlikely that they can even be characterized as good or bad. It may be impossible to determine whether other price and output effects accompany quality changes. Agreements to improve quality may mask agreements to eliminate lower cost alternatives which provide significant price competition to those asserting that such alternatives are of lower quality. ${ }^{89}$ In the long run, consumer choice is reduced and disincentives to further improvement in quality may be created.

To illustrate, suppose that a professional association of dentists agrees that its members will not use substance $X$ in the filling of teeth because, in the collective judgment of its members, fillings made of that substance will not last as long as fillings made of other substances. Use of substance $X$ by a member will result in expulsion from the association. Assuming that durability is the sole difference between substance $X$ and others, quality appears to be enhanced. If substance $X$ is the same price as others, and its use involves all the same costs, the net effect of the agreement might be an increase in quality and nothing more. But this is an unreal scenario. The very fact that the association comes to an agreement on this point suggests that the material is a competitive factor. Dentists informed of the quality difference would presumably opt not to use substance $X$ even without agreement by others (and the association could provide such information without adoption of mandatory standards), unless something more is involved.90 Further analysis shows the following. There is disagreement over the durability not only of substance $X$, but other substances as well. A tooth filled with substance $X$ appears different, because substance $X$ is closer to the natural color of teeth. Some consumers prefer substance $X$ as a cosmetic matter. And while the cost of substance $X$ is the same as other filling substances, some dentists with recent training can use it more efficiently. A number of younger dentists have advertised the material as a lower-cost, more cosmetically appealing alternative. With these added facts, which are likely to be present in an antitrust case, the dilemma is clear. A lower-priced alternative which some consumers prefer has been eliminated to serve a collective quality judgment about which there is a professional disagreement. Assuming that

87. See, e.g., R. Bonk, supra note 14 , at 35 .

88. For example, respondents in Fashion Originators' Guild of Am. v. FTC, 312 U.S. 457 (1941), contended that their boycott of stores selling designs of fashion pirates was lawful because it did not effect prices or output, and did not work "a deterioration in quality." Id. at 466.

89. For a good illustration, see 7 P. AREEDA, supra note 48, at 386 n. 10 .

90. Conceivably, a number of dentists use substance $X$ without informing patients of its shortcomings in order to gain business refilling teeth at an earlier date; this is essentially a deception. 
adverse price effects are significant, and that consumers have relevant information, antitrust should opt for the free market solution.

A second caveat to the broad proposition that the competitive process assures the appropriate quality/price mix should also be noted. If competitors enter into an agreement to fix prices, quality may actually improve. Participants will continue to have incentives to compete and cheat on the cartel. Because of the price benefits accruing to the cartel, its members may seek ways to compete without violating the cartel agreement and thus causing it to break down. Quality competition may take the place of competition in terms of price, and product quality may be improved as a result. ${ }^{91}$ The range of consumer product choices might actually increase. If improvement of quality is our sole concern, cartels might be justified on such grounds. But quality is not the only concern. In this case, quality improvement comes at the cost of the elimination of price competition, which results in higher prices. Consumers desiring lower quality at a lesser price are deprived of that choice. Moreover, while we may be relatively confident that the cartel will cause restricted output and higher prices, there is no assurance that quality will actually improve. ${ }^{92}$ Even if firms cheat, they may do so through product differentiation or other more wasteful forms of rivalry. ${ }^{93}$ The fact that a cartel might result in quality improvement (or prevent quality deterioration) has never been accepted as a ground for softening antitrust's harsh treatment of cartels, and there is no reason why it should.

These principles are directly applicable to cartel behavior in health care markets. If a group of physicians enters into an agreement to fix the prices to their patients, or to establish the rate they will accept as full reimbursement from insurers, they ought not be permitted to defend their actions by asserting that quality will be enhanced. Absent some true efficiency or a relevant market failure (discussed below), conventional cartel rules should apply. This is, in essence, the holding of the Court in Professional Engineers. ${ }^{94}$

The two caveats just expressed-an increase in quality may be an increase in output, and quality competition might increase among cartel membersare not sufficient to alter the basic starting premise that quality is best

91. See R. Posner \& F. Easterbrook, Antitrust 115-16 (2d ed. 1981).

92. See P. Areeda, Antitrust Analysis 9311 (3d ed. 1981). For the argument that monopoly power in physicians will result in a lessening of quality see Sloan \& Feldman, Competition among Physicians, in Competition in the Health Care Sector 45, 66-68 (W. Greenberg ed. 1978).

93. A variation of this scenario is found in the current debate over the quality of services and safety effects of airline deregulation. Critics assert that competition forces a deterioration in quality because competition forces airlines to cut corners. Higher revenues, which might be assured through reestablishment of a government sponsored cartel, will permit firms to expend more on quality control, aircraft maintenance, pilot training, and so on. But there are serious flaws in the argument. Even with a cartel, less efficient producers may still be tempted to cut corners. There is therefore no assurance of higher quality. Firms may simply opt for higher profits or compete by dispensation of free liquor (or something similar). Public safety regulation may more effectively assure the public against harm, without the extraction of monopoly profits and elimination of the public's ability to choose a lower-priced alternative. If the public's ability to choose is constrained by the presence of a monopoly seller, or by inadequacy of information, these market imperfections or failures should be addressed directly.

94. National Soc'y of Professional Eng'rs v. United States, 435 U.S. 679 (1978). 
determined and assured through the competitive process. Given this premise, justifications for provider conduct based upon quality-of-care considerations are relevant when: (1) the conduct ameliorates market failures or imperfections that prevent the market from functioning properly; or (2) the conduct permits providers to deliver services more efficiently; or (3) the enhancement of quality permits providers more effectively to compete with others. Where the determination of competitive effects turns upon the intention with which the alleged violators acted, the intention to increase quality (or prevent its debasement) may also be relevant (although in an antitrust policy predicated on an economic analysis of price and output effects, intent will seldom be a determining factor). In none of these cases are we speaking of a broad quality-of-care defense. Rather, the focus should be on factors commonly examined in all antitrust analysis: market failure, efficiency creation, competitiveness, and, to some extent, intent. Each of these factors will be considered in turn.

b. Market failure and quality of care in health care markets. Discussion of the appropriate role of competition, and therefore of the antitrust laws, in health care markets invariably turns to market failures or imperfections. ${ }^{95}$ Opponents of competition-based reform are quick to assert that health care markets do not, and cannot, function in a manner consistent with the competitive model, and that the interjection of competition will not only fail to bring optimal results in terms of price, output, and quality but may make matters even less optimal than alternative structures. ${ }^{96}$ Health care markets are said to differ from others in several critical ways. The prevalence of third party payment removes cost as a factor in the consumer's decisions about quality/cost tradeoffs. Moreover, consumers do not know what services they need and do not determine who should provide them; these determinations are made by providers themselves. Consumers lack the information, and the ability to evaluate the information, to make informed choices. Because consumers are unconcerned about price and cannot evaluate either the need for or quality of service, a market based upon the competitive model will fail to allocate resources in the most efficient way. ${ }^{97}$ It can be argued that the patchwork of state and federal regulatory interventions in health care markets virtually assures that policies directed toward the interjection of competition

95. See, e.g., Arrow, Uncertainty and the Welfare Economics of Medical Care, 53 Aм. Econ. Rev. 941 (1963); Blumstein \& Sloan, supra note 3, at 867-70; Bovbjerg, supra note 17, at 967-73; Marmor, Broer \& Greenberg, Medical Care and Procompetitive Reform, 34 VAND. L. Rev. 1003, at 1008-06 (1981); Pauly, Is Medical Care Different?, in Competition in the Health Care Sector 11 (W. Greenberg ed. 1978); Weingast, Physicians, DNA Research Scientists, and the Market for Lemons, in Regulating THE Professions 81 (R. Blair \& S. Rubin eds. 1980). Compare Elzinga, supra note 38, at 108-09.

96. This has been the primary economic argument advanced to support both extensive professional self-regulation and government intervention in health care markets. See Blumstein \& Sloan, supra note 3, at 870; Beales, supra note 17, at 125-27; Horowitz, supra note 22.

97. These elements of market "failure" are commonplace in debates over the appropriate public policy with respect to health care. See Havighurst, Competition in Health Services: Overview, Issues and Answers, 34 VAND. L. Rev. 1117 (1981). 
"in the gaps" will accomplish little, and may be counterproductive. 98 Wholesale dismantling of extant regulatory systems, which might solve this problem, may be politically impossible. ${ }^{99}$

Whether these factors require health care structures based on something other than the competitive model is a question beyond the scope of this study, which is focused not on whether the antitrust laws should apply but on how they should apply. At present the question whether the antitrust laws should apply at all has been resolved, but each of these factors may be relevant in the antitrust analysis applied in particular cases. The evaluation of price and output effects cannot ignore third party payment, a highly relevant economic fact. And because the ability of the market to assure optimal quality/cost tradeoffs depends upon the ability to make informed choices, impediments to such choices are directly relevant to the evaluation of quality-of-care considerations. Whether the particular conduct at issue in a given antitrust case is anticompetitive in the consumer welfare sense may depend upon the relationship between such conduct and the imperfections present in the market. In some cases, quality/cost tradeoffs may be optimized through conduct that removes such imperfections.

The relevance of third party payment on a fee-for-service basis to the quality of health care is not obvious. Consumers not constrained by limited resources, and therefore unconcerned about cost, will elect the best care available, to the extent they make choices at all. Similarly, where demand is determined by providers, as is often the case, there is no reason to believe that third party payment is a factor in limiting the quality of care provided. Unconstrained by considerations of cost, doctors and other providers are likely to opt for more and better services, not less. The prevalence of fee-forservice payment by insurers or the government has been justly criticized on efficiency grounds and for overallocating resources to health care, ${ }^{100}$ but not for reducing quality. The quality concern frequently voiced is precisely the opposite-that departures from the traditional fee-for-service third party payment system will impair quality. Efforts by insurers, alternative health plans, and regulators to constrain, if not reduce, costs through use of the existing payment system or the creation of competitive alternatives have been and will continue to be resisted by providers and even some consumers on quality-of-care grounds. ${ }^{101}$ It is in this context that the issue is likely to be raised in antitrust cases. If third party fee-for-service payments contribute to failure of health care markets to perform in an economically efficient manner, should this failure persist in order to assume quality?

98. See Blumstein \& Sloan, supra note 3 , at 854.

99. See McClure, Implementing a Competitive Medical Care System through Public Policy, 7 J. Health Pol. Pol'y \& L. 2, 8-9 (1982).

100. See, e.g., Bovbjerg, supra note 17, at 967-73; Feldman, The Impact of Third-Party Payment on Professional Practice: Lessons from the Medical Profession, in Regulating the Professions 245 (R. Blair \& S. Rubin eds. 1980).

101. See, e.g., Michigan State Medical Soc'y, 101 F.T.C. 191 (1983) (Medicaid "boycott"). 
As an example, consider physicians who boycott insurers because they view the amounts they receive from insurers as inadequate for the provision of quality care. ${ }^{102}$ This type of activity may become more common as insurers, driven by increasing competition among themselves and with alternative care systems such as HMO's, or by pressure from regulators or other sources, seek more aggressively to contain costs by departing from traditional reimbursement plans. In its simplest form, the quality-of-care justification in this setting may be little more than an assertion that with more money better care will be provided. To uphold a significant price restraint on these grounds would be unacceptable under an antitrust analysis which presupposes that quality/cost tradeoffs are optimized through the competitive process. The conduct is designed to preserve the benefits of a structural factor contributing to a degree of market failure, rather than to eliminate or modify the effect of such failure. Market failures or imperfections may be used in justifying otherwise unlawful restraints only with respect to conduct that tends to perfect a market.

The market failure argument advanced to justify such a boycott might be more complex than just suggested. Departures from traditional fee-forservice insurance plans which are driven by and premised on competitive market forces cannot be expected to optimize cost/quality tradeoffs because of a second imperfection in the market, the consumer's inability to make informed choices. Cost constraints in such circumstances will lessen quality because they constrain physicians in the services they can provide to all consumers. Unless all market imperfections are ameliorated, there is no reason to believe that the competitive process can assure quality of care. Provider determinations about quality ought not be displaced by judgments of insurers or the government, who are less qualified.

This argument assumes either that insurers do not share the consumer's interest in quality of care, or that they too are unable to make informed quality/cost tradeoffs. Neither proposition is self-evident. Insurers in competitive markets cannot market insurance plans that fail to satisfy the needs of the consumers within their plans. Most insurance plans are marketed to employers, often acting in conjunction with labor unions. These purchasers may be expected to demand quality and to look for plans that meet those needs. This surrogate effect with respect to quality was recognized in Indiana Federation of Dentists. ${ }^{103}$ Political pressures are likely to drive the government in the same way. Moreover, in the long run, insurers must have a

102. See, e.g., Ratino v. Medical Service of the District of Columbia, 718 F.2d 1260 (4th Cir. 1983) (agreement on rates to be reimbursed by insurers); Michigan State Medical Soc'y, 101 F.T.C. 191 (1983). See generally Raup, supra note 10.

103. FTC v. Indiana Fed'n of Dentists, 476 U.S. 447, 463 (1986) ("[Insurers] are themselves in competition for the patronage of the patients-or, in most cases, the unions or businesses that contract on their behalf for group insurance coverage-and must satisfy their potential customers not only that they will provide coverage at reasonable cost, but also that that coverage will be adequate to meet their customers' . . needs."). 
strong interest in quality in order to reduce their own costs. ${ }^{104}$ Inadequate care is likely, in the long run, to increase those costs. The fact that consumers may not be able to make informed judgments about quality of care is therefore not critical if those upon whom they rely, providers and insurers, have incentives to optimize quality/cost tradeoffs and have the information upon which to make judgments. This is not of course a complete answer to the argument just suggested. Insurers may also lack information, although to a lesser degree, and, like consumers, are confronted with considerable uncertainty. Again, however, this is fundamentally an argument that health care markets are so characterized by failure that the antitrust laws should not apply at all. While justifications of conduct that tends to perfect markets are consistent with consumer welfare analysis, preservation of inefficiency caused by a traditional fee-for-reimbursement system-because the market is imperfect in another respect-is inconsistent with the basic premises of the consumer welfare model.

There are, however, activities by provider groups and others with respect to health care markets that improve the functioning of the market by correction of market failures and imperfections. These activities are procompetitive in the consumer welfare sense. Quality-of-care justifications may in fact involve such corrections. If so, the justification is relevant. It should be noted, however, that the focus is on market failure and not directly on quality of care, which is but an incident to improvement in the competitive process.

The most obvious examples relate to joint activities that assist informed decisionmaking about quality/cost tradeoffs by providing information and advice, eliminating deception, or increasing the comparability of providers and services. ${ }^{105}$ Certification and accreditation programs are likely, for example, to provide useful information about quality of services (or at least more useful information than is otherwise available). ${ }^{106}$ Professional selfregulation that reduces deception, may also be characterized as lessening market imperfection, particularly where, as in health care markets, consumers

104. The provision of inadequate care to insureds will in many cases result in higher total treatment costs for those individuals, costs which the insurer must reimburse. Assuming that the insurer has incentives to reduce its own costs, it has an efficiency interest in the quality of care provided its insureds. Where the insurer is in direct competition with other insurers, it will have strong incentives to reduce its costs. If, however, the insurer is a monopolist, it may not be driven to reduce its costs to the same degree. This is a point over which there is some disagreement. Compare R. Posner, supra note 80, at 15-16, with H. Hovenkamp, Economics and Federal Antitrust Law 21 24 (1985). An insurer who is simply the alter ego of or controlled by providers may also lack incentives to lower costs, to the extent that cost reduction would be contrary to the controlling providers' interests. See, e.g., Havighurst \& McDonough, The Lithotripsy Game in North Carolina: A New Technology Under Regulation and Deregulation, 19 IND. L. REV. 989, 1016-20 (1986).

105. See generally Leibenluft \& Pollard, Antitrust Scrutiny of the Health Professions: Developing a Framework for Assessing Privale Restraints, 34 VAND. L. REv. 927, 947-49 (1981). Some product standardization agreements, for example, may enhance competition by increasing the comparability of the products of a number of different producers. See, e.g., L. Sullivan, AntrTrust \& 98, at 275-77 (1977).

106. See generally Havighurst \& King, supra note 11; Kissam, supra note 47. 
lack adequate information and are therefore easily misled. ${ }^{107}$ Evaluation of the informational effects of a broad range of professional activities must recognize that judgments about quality/cost tradeoffs are made in large part by actors in the market other than consumers. Because of the combination of third party payment and uncertainty, consumers in effect delegate a substantial number of these decisions to providers and insurers. ${ }^{108}$ Information of little value to consumers may be useful to physicians. The same may be true with respect to insurers. For example, accreditation of a hospital may mean little to consumers, who have no understanding of the standards applied by accrediting bodies. But the information and professional judgment embodied in accreditation may be extremely useful to physicians and insurers. The value of information must be measured with reference to all who participate in the market.

Accreditation and certification programs may also have significant anticompetitive effects. They may be used by a dominant professional group to deny market access to competitors, and to facilitate cartels. ${ }^{109}$ Where such adverse effects predominate or result from conduct going beyond that reasonably necessary to the provision of information valuable to consumers and others who make market decisions, such programs violate current antitrust standards. Where confined to activities that inform the process, and to restraints reasonably ancillary to this end, they are both legitimate and lawful.

c. Productive efficiency and quality of care. In some cases, arguments couched in quality-of-care terms are really claims that by reason of integration or otherwise the conduct in question increases productive efficiency and reduces costs. This was true, for example, of the contention in Hyde that a contract granting the exclusive right to provide anesthesiology services in the

107. See, e.g., National Soc'y of Professional Eng'rs, 435 U.S. 679, 696 (1978); American Medical Ass'n, 94 F.T.C. 701,1009 (1979), aff'd, 638 F.2d 443 (2d Cir. 1980). I do not suggest that professional rules related to such matters as advertising and solicitation as an historical matter were necessarily motivated by a desire to eliminate deception and thus enhance competition. The motives for such rules are likely to have been mixed at best. Traditional rules on professional advertising and solicitation directly restrain competition, and may have been intended to do so. But narrowly drawn rules targeted directly at deception may have beneficial informational effects. It may also be that courts and agencies dealing with the validity of such rules have been led to permit a continuation of professional self-regulation dealing with deception, as was the case in the AMA litigation, more out of a sense of good politics than a true concern with deception. But even if this were so, the effect of eliminating deception is procompetitive.

108. The delegation from patient (agent) to physician (principal) on medical care matters is often seen as a given. See, e.g., Beales, supra note 17, at 125-27; Bovbjerg, supra note 17, at 967-68; Weingast, supra note 95, at 81 . The delegation from insured to insurer is less clear. But decisions by insurers about what care is appropriate, and therefore reimbursable, will in many cases displace the insured's own judgment. Cf. FTC v. Indiana Fed'n of Dentists, 476 U.S. 447, 463 (1986).

109. Where sellers are few, the setting of uniform product standards may facilitate collusion by making it easier for cartel members to detect cheating. See H. HovenkamP, supra note 104, at 101; L. Sullivan, supra note 105 , at 280 . Accreditation and certification programs involving health care markets will often involve too many providers for such an effect to be a plausible concern. The more common adverse effect will be found in the use of such programs to exclude and thereby competitively handicap providers or groups of providers who do not satisfy the standards adopted. See, e.g., Havighurst \& King, supra note 11 , at 173. 
hospital's facilities permitted more effective monitoring of the quality of service provided. ${ }^{110}$ There was no suggestion that such monitoring could not occur without an exclusive contract. The claim was that an exclusive contract provided a more efficient means of doing so. Similarly, denial of hospital staff privileges to a physician or other provider who has a history of disrupting hospital operations through bad personal relationships raises questions relating to the efficiency of hospital operations." In these cases, quality is not the real issue, and no measurement of quality is necessary. Increased efficiency may improve quality as a by-product. Reduction in the cost of providing service at a particular quality level may also result in a lowering of price and greater availability of the service.

Efficiency claims are cognizable in an antitrust analysis predicated on price and output effects in several different ways. Per se rules are not applied to categories of conduct that may be efficiency-creating. ${ }^{112}$ Where the conduct under attack involves an integration of operations that may result in significant efficiencies, the rule of reason is applied. ${ }^{113}$ Conduct which "injures" competitors solely through efficiency is not anticompetitive. ${ }^{114}$ It is possible that conduct could simultaneously create market power and increase efficiency. In such a case the determination of price and output effects theoretically requires that efficiency gains be balanced against the effects of increasing market power. ${ }^{115}$ How and if such balancing can or should occur is a fundamental issue in antitrust analysis which is generally beyond the scope of this study. ${ }^{116}$ The point for present purposes is that antitrust analysis does take efficiencies into account, and that quality-of-care claims which on closer examination are assertions of efficiency creation are relevant and should be treated like any other efficiency claims. ${ }^{117}$

110. Jefferson Parish Hosp. District No. 2 v. Hyde, 466 U.S. 2, 43 (1984) (O'Connor, J., concurring).

111. The issue was squarely placed in efficiency terms in Weiss v. York Hosp., 745 F.2d 786, 820 n.60 (3d Cir. 1984), cert. denied, 470 U.S. 1060 (1985). For other antitrust cases in which disruptive behavior played a significant part in a hospital's decision to deny or terminate staff privileges, see, for example, Pontius v. Children's Hosp., 552 F. Supp. 1352 (W.D. Pa. 1982); McElhinney v. Medical Protective Co., 549 F. Supp. 121 (E.D. Ky. 1982). For a general discussion of the legal issues involving such staff members, see Springer \& Casale, Hospitals and the Disruptive Health Care Practitioner-Is the Inability to Work with Others Enough to Warrant Exclusion?, 24 DuQuesne L. Rev. 337 (1985).

112. Broadcast Music, Inc. v. Columbia Broadcasting Sys., Inc., 441 U.S. 1, 20-21 (1979); Continental T.V., Inc. v. GTE Sylvania, Inc., 433 U.S. 36, 54-55, 58 (1977).

113. L. Sullivan, supra note $105, \S 77$, at 206-10.

114. Although the Supreme Court appeared to suggest otherwise in Brown Shoe Co. v. United States, 370 U.S. 294, 334-46 (1962), the idea that competition can be harmed through increases in productive efficiency has been "implicitly abandoned." $H$. HovenKamP, supra note 104, at 297. Today, competitors "injured" solely by efficiency suffer no cognizable "antitrust injury." Id. at 37376.

115. R. BORK, supra note 14, at 123-29; H. Hovenkamp, supra note 104, at 299.

116. I have discussed this problem in more detail elsewhere. See Kauper, Comment: The Sullivan Approach to Horizontal Restraints, 75 CALIF. L. Rev. 893, 913-15 (1987).

117. Evaluation of less restrictive alternatives, for example, should be required in health care cases to the same extent that it is part of the analysis in antitrust cases generally. See supra text at notes 169-70. 
In some health care cases, defendants have sought to justify restraints as a means of avoiding legal liability for malpractice, or improper or inadequate treatment. ${ }^{118}$ While not usually done, the argument can be put in efficiency terms. Liability is a potential cost to providers. Premiums for insurance against such liability are a cost with which providers must cope. Providers able to reduce these costs may have a significant advantage over those who are unable to do so. Provider conduct that lowers the risk of such liability, and that may therefore reduce insurance costs, may be characterized as efficiencycreating. ${ }^{119}$ However, liability insurance premiums may not be sufficiently sensitive to permit specific providers with good risk history to obtain lower rates. The argument here presented assumes that they are. The benefits consumers receive in the form of better health care are a result of actions taken by providers for efficiency reasons, and not out of some sense of public service. These efficiencies should be taken into account in antitrust analysis as others are.

Consider once again the typical hospital staff privileges case. Dr. $X$ applies for staff privileges at Hospital $Y$. Upon recommendation of its medical staff, some of whom practice the same specialty as $\operatorname{Dr} . X$, Hospital $Y$ denies the application. The record in the ensuing antitrust litigation reveals that Dr. $X$ has had an extraordinarily large number of malpractice suits filed against him. Large settlements have been paid. A hospital in a distant city has withdrawn staff privileges on grounds of incompetence. Most cases of this type never reach quality-of-care issues. They are dismissed for want of effect on interstate comerce, ${ }^{120}$ or because the hospital's actions are within the state action exemption, ${ }^{121}$ or for a variety of other reasons. ${ }^{122}$ However, additional

118. See, e.g., Friedman v. Delaware County Memorial Hosp., 672 F. Supp. 171, $191-92$ (E.D. Pa. 1987); Kaczanowski v. Medical Center Hosp. of Vt., 612 F. Supp. 688, 695-96 (D. Vt. 1985); Vuciecevic v. MacNeal Memorial Hosp., 572 F. Supp. 1424, 1428 (N.D. Ill. 1983); Williams v. Kleaveland, 1983-2 Trade Cas. (CCH) \& 65,486, at 68,358 (W.D. Mich. 1983). Cf. Tripoli Co. v. Wella Corp., 425 F.2d 932 (3d Cir. 1970) (en banc) (upholding vertical customer restriction in part because it protected seller from potential product liability). Commentators have suggested that antitrust liability ought not be imposed where the acts in question reduce potential tort liability, but have not generally put the argument in efficiency terms. See, e.g., Note, Health Professionals ${ }^{\circ}$ Access to Hospitals, supra note 7, at 1194. See also Kissam, Webber, Bigus \& Holzgraefe, supra note 6 , at 602 (describing the "need to reach an accommodation between the goals of antitrust law and the practical and legal effects of medical malpractice law" and hospital liability for inadequate staff supervision as a "central problem" which "appears within virtually all substantive antitrust issues dealing with privileges.")

119. See Denying Hospital Privileges, supra note 6, at 1219, 1242 (correctly noting that conduct that decreases potential liability is procompetitive because it reduces costs).

120. For recent examples, see Pariser v. Christian Health Care Sys., Inc., 816 F.2d 1248, $1252-53$ (8th Cir. 1987); Stone v. William Beaumont Hosp., 782 F.2d 609, 614 (6th Cir. 1986); Shehawy v. Harrison, 755 F.2d 1432 ( 1 l th Cir. 1985). For a full discussion and collection of cases see Marrese v. Interqual, Inc., 748 F.2d 373, 379-82 (7th Cir. 1984), cert. denied, 472 U.S. 1027 (1985).

121. In Marrese v. Interqual, Inc., 748 F.2d 373, 395 (7th Cir. 1984), cert. denied, 472 U.S. 1027 (1985), the court held that termination of a surgeon's staff privileges pursuant to Indiana's statutory peer-review process was exempt from federal antitrust laws under the "state action" exemption. Marrese was followed by the Ninth Circuit, in Patrick v. Burget, 800 F.2d 1498, 1506-07 (9th Cir. 1986), with respect to Oregon legislation, a decision subsequently reversed by the Supreme Court. 108 S. Ct. 1658 (1988). For other cases, see Posner v. Lankenau Hosp., 645 F. Supp. 1102 , 1118 (E.D. Pa. 1986) (rejecting the reasoning of Marrese); Quinn v. Kent Gen. Hosp., Inc., 617 F. Supp. 
facts could make the case more compelling. Dr. $X$ is in a specialty that is practiced by only two other physicians, both of whom are on the staff of Hospital $Y$, the only hospital in the area. It is not possible to practice the specialty without access to hospital facilities. Dr. $X$ denies his incompetence. This now looks more like a real antitrust case. The hospital now asserts that if it grants Dr. $X$ privileges, then its own risk of legal liability will be substantially increased. Assuming that the factfinder concludes that $\mathrm{Dr} . X$ is incompetent, and that granting staff privileges to a physician the hospital knows or should know is incompetent will increase the hospital's risk of liability, its action reduces its costs.

Does recognition that lowering the liability risk and the cost of liability insurance is an efficiency create a virtually unlimited quality-of-care defense? In other words, can any restraint which improves quality be said to be efficiency-creating because it reduces insurance costs generally? The answer is no, for several reasons. In the case posited, the hospital has arguably reduced its own costs, where the very act of admitting Dr. $X$ to staff privileges in itself could create liability. ${ }^{123}$ Moreover, in making judgments about legal liability a court is applying legal standards familiar to it. The standard applied-whether the hospital's granting of staff privileges is an exercise of reasonable care-does not require the identification and measurement of quality in any absolute sense. Finally, even in the staff privileges case, the reduction in costs that might result is simply a factor in the analysis, to be treated no differently than other reductions in costs, and is not an absolute defense. Thus, for example, efficiencies may not be used to justify conduct that enhances market power if they may be obtained in a less restrictive manner. ${ }^{124}$

d. Quality of care as an element of rivalry. Firms compete not only on price, but also on quality of product or service. Both are integral factors in the consumer's decision to buy. The premise that quality/cost tradeoffs are maximized through rivalry among competitors rests on this proposition. Agreements among firms to eliminate quality rivalry through product standardization or in some other fashion may have adverse consumer welfare

1226, 1238-39 (D. Del. 1985) (rejecting the reasoning of Marrese). This result will vary from state to state. See Tambone v. Memorial Hosp. for McHenry County, 635 F. Supp. 508, $514-16$ (N.D. Ill. 1986) (Illinois peer-review legislation differs sufficiently from Indiana's that Marrese does not apply). The "state action" issue as it relates to hospital peer review is discussed in detail in Blumstein \& Sloan, supra note 6 , at 34 .

122. The issue of conspiracy for purposes of section 1 of the Sherman Act has been particularly troublesome in staff privileges cases. Whether physicians on the staff may conspire with each other, or with the hospital itself, is an issue over which there is some disagreement. The answer may turn on the relationship of a particular hospital and the physicians involved. The "conspiracy" issue is fully discussed in Blumstein \& Sloan, supra note 6, at 39-53.

123. Negligent supervision or screening of its staff by a hospital may itself create a tort liability in the hospital. The leading case is Darling v. Charlestown Community Memorial Hosp., 33 Ill. 2d 326 , 211 N.E. 2d 253 (1965), cert. denied, 383 U.S. 946 (1966). The very act that allegedly constitutes the antitrust violation is the same act that lessens the risk of tort liability.

124. See infra text at notes 171-72. 
effects; they may represent a restriction of output. ${ }^{125}$ Such agreements may also facilitate price collusion. ${ }^{126}$ Conversely, conduct by single firms to enhance quality, or perhaps more accurately their reputation for quality, contributes to their ability to compete and thus to the competitiveness of the marketplace. The so-called goodwill defense in tying cases, ${ }^{127}$ for example, rests on the procompetitive effect of protection of reputation.

The quality-of-care defense offered in some health care cases is an assertion that the challenged provider conduct promotes rivalry through protection of reputation. The most obvious example is a hospital's denial of staff privileges to a physician who is simply incompetent, or has a public reputation of incompetence. The hospital will contend that the effect of its action is to prevent debasement of the quality of care its patients receive. It is not, however, acting out of some purely altruistic, public service concern. The presence of such a physician on the staff will damage the hospital's reputation, and thus its ability to compete. ${ }^{128}$ It may also injure the reputation of other members of the staff through association, although this effect is less obvious. If these effects are strong enough, the hospital may lose

125. See supra text at note $\mathbf{8 8}$.

126. Agreements with respect to quality may eliminate differences among products and thus make it easier to detect cheating on the cartel price. Such agreements may also be used to eliminate lower-priced products which put price pressure on the market. See supra notes 89, 109.

127. The goodwill defense rests on a showing that a tying arrangement is necessary in order to assure that the reputation of the tying product is not injured when the buyer uses with it an inferior product, or a product that otherwise damages or causes the tying product to malfunction. The Supreme Court has rejected the defense each time it has been presented, on the ground that in each case contractual specifications would afford adequate protection without a tying arrangement. See Jefferson Parish Hosp. District No. 2 v. Hyde, 466 U.S. 2, 26 n.42 (1984). The defense has been accepted in lower court cases where less restrictive alternatives have been found inadequate. See Mozart Co. v. Mercedes-Benz of North Am., Inc., 833 F.2d 1342, 1348-51 (9th Cir. 1987); Dehydrating Process Co. v. A.O. Smith Corp., 292 F.2d 653, 556-57 (lst Cir.), cert. denied, 368 U.S. 931 (1961); Telaflex Indus. Prods., Inc. v. Brunswick Corp., 293 F. Supp. 106, 109 (E.D. Pa. 1968); United States v. Jerrold Elecs. Corp., 187 F. Supp. 545, 556-58 (E.D. Pa. 1960), aff'd per curiam, 365 U.S. 567 (1961). The Supreme Court's treatment of the defense has rested on the availability of less restrictive alternatives and is not a rejection of the competitive desirability of protecting reputation for quality.

128. See, e.g., Weiss v. York Hosp., 745 F.2d 786, 820 n.60 (3d Cir. 1984), cert. denied, 470 U.S. 1060 (1985), where the court correctly observed that:

[B]y restricting staff privileges to doctors who have achieved a predetermined level of medical competence, a hospital will enhance its reputation and the quality of the medical care it delivers. Thus such action is pro-competitive Accord Robinson v. Magovern, 521 F. Supp. 842, 919 (W.D. Pa. 1981), aff'd, 688 F.2d 824 (3d Cir.), cert. denied, 459 U.S. 971 (1982); Pontius v. Children's Hosp., 521 F. Supp. 1352, 1365 (W.D. Pa. 1982). See also Potters Medical Center v. City Hosp. Ass'n, 800 F.2d 568, 576 (6th Cir. 1986), where the court observed that while the enhancement of reputation for quality is normally procompetitive, this may not be the case when the hospital is a monopolist (presumably because the hospital does not have anyone to compete with in quality terms). Not all staff privileges cases have perceived that there is a correlation between reputation for quality and competitive rivalry. See Quinn v. Kent Gen. Hosp., Inc., 617 F. Supp. 1226, 1224 (D. Del. 1985), where the court apparently saw quality as a noncompetitive benefit to patients which must somehow be balanced against adverse effects "in the market for hospital facilities."

Given the prevalence of third party payment, reputation for quality is a critically important factor in the competitive rivalry among hospitals. Price adjustments are likely to have little competitive impact. See Salkever, Competition Among Hospitals, in Competition in the Health Care Sector 149 , 155, 157 (W. Greenberg ed. 1978). 
patients not only through consumer choice but because other physicians, fearful for their own reputations, leave the staff, taking their patients with them. ${ }^{129}$

A court called upon to decide such a case need not consider these effects unless the denial of staff privileges is likely to have adverse price and output effects in the market served by the denied physician. In most cases, such effects are likely only when staff privileges are competitively significant, where these competitively significant benefits are not reasonably obtainable elsewhere, and where the number of competing physicians with such privileges is small. Under these circumstances, the denial of entry may protect a cartel among those already established. ${ }^{30}$ Few denials of staff privileges to individual physicians (or other providers) are likely to have such adverse price and output effects. ${ }^{131}$ But where they do, the reputational effects of granting privileges become relevant and should be treated in the same manner as efficiencies. The likelihood of these effects must be evaluated on the record. The problems of defining quality should not be an obstacle here. The focus is more on reputation than quality as such. It is not necessary to define quality in some absolute sense. The standard will generally be akin to that applied in malpractice and similar tort cases. In addition, the restraint imposed should not be broader than necessary to protect reputation. As with efficiencies, the injury to reputation will not be considered if reputation can be equally safeguarded in a less restrictive manner. ${ }^{132}$

In the staff privileges case just discussed, the adverse reputational impact, if any, occurs because if staff privileges are granted, the incompetent physician is identified in the minds of consumers with the hospital. In a number of cases in which broad quality-of-care claims have been advanced, this will not be the case. Suppose, for example, that a professional association of physicians boycotts an insurance company because it reimburses consumers who use the services of chiropractors. The doctors assert that the elimination of chiropractors will improve the quality of care because chiropractic care is both inferior and dangerous. Even assuming that this assertion could somehow be established, the boycott will not improve the quality of care, nor the reputation for quality of care, provided by the boycotting physicians. There is no reason to believe that consumers associate chiropractors with physicians.

129. Physicians with staff privileges are the medium through which the hospital obtains patients If a hospital loses physicians from its staff, it loses hospital patients as well.

130. The exclusion of a single competitor from a hospital staff will likely work little hardship even on the individual's ability to compete if he or she has comparable hospital access elsewhere in the community. Moreover, even if the excluded provider is competitively handicapped, there will be no adverse price and output effects unless the group from which he or she has been excluded has both the ability to collude and the power to raise price if they do. In normal circumstances, denial of staff benefits to individuals is of little consequence unless the hospital has substantial market power, or there is other evidence of collusion in the market.

131. Adverse effects are more likely where an entire class of competitors or potential competitors (e.g., podiatrists, nurse-midwives) are denied hospital access. See text at notes 7, 251; Denying Hospital Privileges, supra note 6, at 1240-47.

132. See infra text at notes 169-70. 
The relevance of quality (and reputation for quality) as an element of the competitive rivalry principle here discussed is subject to still other limitations. Unless there is no correlation between quality and consumers' perceptions about it, quality must be directly evaluated. ${ }^{133}$ Antitrust analysis rests on the proposition that the market decides the appropriate quality/cost tradeoffs. Judges cannot, consistent with such analysis, define and decide what constitutes quality improvement. At the most, judges can make determinations that a given procedure or actor is one that no significant number of consumers with full knowledge would choose. ${ }^{134}$ Finally, in many cases the clear availability of less restrictive means to the same end will defeat reliance on such justification.

To illustrate, assume an agreement among hospitals not to employ a particular procedure (or piece of equipment) because, in their collective judgment, the procedure is worthless in all cases and dangerous in most. The non-use of such a procedure might improve quality, and therefore each hospital's ability to compete. If the procedure is truly dangerous, the decision not to use it might enhance each hospital's reputation for quality. Conceivably, a court could determine that a specific procedure has no worth to anyone. But this is not likely to be the case. Some may disagree over its efficiency or dangerousness. It may be that it is of value to a small number of terminally ill patients with full knowledge of the risks, which in their case are worth taking. The very fact that the hospitals feel compelled to agree not to use the procedure suggests that it would be elected by some (although it might be chosen only by persons with inadequate information). ${ }^{135}$ The market then should make the determination. ${ }^{136}$ In addition, the argument that rivalry will be enhanced is weakened by the uniformity of the agreement. Where all rivals agree, there is no effect on rivalry at all. ${ }^{137}$ Finally, this is a circumstance where, if the case is as the hospitals say it is, there is no need for agreement. Every hospital with full knowledge about the procedure would elect not to use it on its own.

133. In some cases, consumers' perceptions might be evaluated directly. But normally those perceptions must be presumed to be in accord with the quality-of-care level itself. Thus the quality must somehow be evaluated. As an alternative, some might suggest that the critical issue is whether the parties' purpose was to enhance quality of care. A purpose to improve quality is some evidence that such improvement will occur, but even if such a purpose is clear, the standard cannot rest on purpose alone. See infra text at notes 129-49.

134. This will likely be the case where the issue is an incompetent provider, or a procedure that is medically useless. There may also be instances in which consumers who lack full information perceive quality to be different than it really is. For example, consumers might perceive that a given procedure is dangerous when it is not. Since quality rivalry is a matter of perception, provider responses based upon this perception may be viewed as procompetitive. But in many such cases the provision of full information is an adequate less restrictive alternative.

135. Provision of adequate information without further agreement about the procedure would itself be procompetitive.

136. Alternatively, the state could make the political judgment to eliminate the procedure.

137. Cf. Potters Medical Center v. City Hosp. Ass'n, 800 F.2d 568, 577 (6th Cir. 1986) (enhancement of quality not necessarily procompetitive where hospital lacks rivals). 
e. Purpose as an element in health care cases. Courts and commentators on occasion have suggested that with some types of conduct, a predicate to antitrust liability is a determination that the conduct was accompanied by a purpose to injure competition. ${ }^{138}$ If a bad purpose is necessary to establish a violation in a given case, proof of a good purpose is relevant to negate proof of a purpose which is bad. ${ }^{139}$ In a variation of the theme, it has been argued that while violation does not depend upon a bad purpose, conduct which does not have a commercial purpose is outside the scope of antitrust. ${ }^{140}$ If the

138. The insistence on a purpose (or intent) to injure competition appears most commonly in commentaries and cases involving monopolization, attempts to monopolize, and boycotts. A number of early monopolization cases spoke primarily in terms of a purpose or intent to monopolize or restrain trade. See, e.g., Standard Oil Co. v. United States, 221 U.S. 1, 75 (1911). Later cases have rejected a purpose-based standard and have made liability turn on an objective judgment about the nature of the acts in question. See, e.g., Olympia Equip. Leasing Co. v. Western Union Tel. Co., 797 F.2d 370, 379 (7th Cir. 1986), cert. denied, 480 U.S. 934 (1987); United States v. Aluminum Co. of Am., 148 F.2d 416, 431-32 (2d Cir. 1945). See generally 3 P. Areeda \& D. Turner, Antitrust Law 9 626 (1978). The broad general standard for attempts to monopolize, however, continues to speak of the need to establish a specific intent to obtain a monopoly or exclude competitors. See Cooper, Altempts and Monopolization: A Mildly Expansionary Answer to the Prophylactic Riddle of Section 2, $72 \mathrm{MICH}$. L. REv. 373, 392-400 (1974). Again, specific intent has come to mean little more than that the defendant is presumed to intend the consequences of its acts. See P. Areeda \& D. Turner, supra, at $\eta$ 822. Reliance on anticompetitive purpose as a predicate of liability, or on good purpose to exonerate from liability (or at least from application of a per se rule), is more common in cases in which boycotts are alleged. See infra note 148 .

Intent is an element of proof in criminal cases brought under the Sherman Act, although even in such cases the government need only establish that acts with anticompetitive effects were undertaken with knowledge of their consequences. See United States v. United States Gypsum Co., 438 U.S. 422, 444 (1978).

139. Throughout this discussion "purpose" and "intent" are used interchangeably. Some commentators have distinguished among these terms, characterizing "intent" as the desire of individuals or groups to effect means that could accomplish particular goals, while stating that "purpose" refers to the goals or objectives themselves. See Kissam, Antitrust Boycolt Doctrine, 69 Iowa L. Rev. $1165,1180-81$ (1984); Coons, Non-Commercial Purpose as a Sherman Act Defense, 56 Nw. U. L. REv. 705, 709-2 (1962). The distinction is not critical for consideration of the particular issue at hand, namely, whether a good purpose (or intent) provides a defense for conduct otherwise shown to have adverse price and output effects. When purpose is said to be of relevance in determining effects, the reference is to goals or objectives.

140. See, e.g., Marjorie Webster Junior College v. Middle States Ass'n of Colleges and Secondary Schools, 432 F.2d 650, 654 (D.C. Cir. 1970), cert. denied, 440 U.S. 965 (1970); Selman v. Harvard Medical School, 494 F. Supp. 603, 621 (S.D.N.Y. 1980), aff d, 636 F.2d 1204 (2d Cir. 1980) (academic admissions criteria legitimate because non-commercial); Nara v. American Dental Ass'n, 526 F. Supp. 452, 457-458 (W.D. Mich. 1981). The cases are discussed in Havighurst \& King, supra note 11, at $170 \mathrm{n} .125$; Kissam, supra note 41 , at $47-48 \mathrm{n} .258$. The presence of a non-commercial purpose may also be used to avoid the application of per se rules, rather than to take the case out of the antitrust laws altogether. See, e.g., Kreuzer v. American Academy of Periodontology, 558 F. Supp. 683, 684-685 (D.D.C. 1983), aff 'd, 735 F.2d 1479 (D.C. Cir. 1984); McElhinney v. Medical Protective Co., 549 F. Supp. 121, 133 (E.D. Ky. 1982), rev d on other grounds, 1984-1 Trade Cas. CCH † 66,054 (6th Cir.); Note, The Professions and Noncommercial Purposes: Applicability of Per Se Rules Under the Sherman Act, 11 U. MICH. J.L. REF, 387 (1978). This more limited use of non-commercial purpose may be seen as little more than recognition that in such cases effects may be sufficiently uncertain that a full rule of reason inquiry is needed.

The concept of non-commercial purpose in antitrust analysis goes beyond the activities of professionals. See Coons, Non-Commercial Purpose as a Sherman Act Defense, 56 Nw. U.L. Rev. 705 (1962); Note, Now or Never; Is There Antitrust Liability for Noncommercial Boycotts?, 80 CoL. L. REv. 1317 (1980) (focus on non-commercial boycotts as those involving an element of political action, where first amendment values are involved). But recent cases and commentary relying on the commercial/non-commercial distinction have all involved professional activity, and have rested in part on the admonition in Goldfarb that professions might be treated differently (see Nara, $526 \mathrm{~F}$. 
motive of the actors is not related to their economic interests, their conduct is secure from antitrust attack. These two concepts of purpose are not coterminus. Not every commercial purpose is one to injure competition. If either of these positions is correct, a purpose to improve quality of care or to protect patients from improper or unsafe treatment is relevant in conventional antitrust analysis, without regard to whether the professions or health care providers are treated differently for antitrust purposes than anybody else. If the sole purpose is to safeguard patients, the purpose is not to injure competition. If all that motivates the conduct is a sense of professional responsibility, the purpose can be said to be non-commercial. ${ }^{141}$

A detailed examination of the relevance of purpose in antitrust analysis generally is beyond the scope of this paper. It is sufficient for present purposes to note that antitrust focuses on effects, or, in some cases, likely effects. ${ }^{142}$ A worthy purpose will not save conduct with adverse price and output effects. ${ }^{143}$ If such effects are present, the violation is no worse if accompanied by a purpose to achieve them. Conversely, if the conduct promotes efficiency or otherwise promotes competition, it will not be condemned. Much the same may be said about the distinction between commercial and non-commercial purpose. That the parties acted for commercial reasons does not inform a judgment with respect to adverse competitive effects; the enhancement of efficiency, for example, is a commercial purpose. And even a non-commercial purpose will not justify conduct where the effects are in fact anticompetitive.

Purpose is relevant only as a guide to a judgment about effects, both adverse and beneficial. ${ }^{144}$ Where those who know a market act for the avowed purpose of restraining it, their intention is some evidence that adverse effects will occur. ${ }^{145}$ Similarly, an unambiguous intention to promote efficiency is probative in determining whether conduct does so. Such proof of course may also negate the attempt by plaintiff to establish the opposite, that the purpose was to restrain competition. The role of purpose is evidentiary. Standing alone, it can neither justify nor condemn. Only when direct evidence of adverse effects is lacking or ambiguous, and the inferences drawn from conduct alone are not compelling, is there reason to examine motive. A good

Supp. at 457-58); they do not stand for the proposition that the distinction is part of a broader antitrust analysis.

Finally, it should be noted that whatever the relevance of purpose in a consumer welfare-based antitrust analysis, there is no logical reason to distinguish between a non-commercial purpose and a commercial purpose to increase efficiency or gain a competitive advantage, which are at least equally legitimate.

141. See Note, supra note 140 , at 398-407.

142. See the excellent discussion in 7 P. AREEDA, supra note 48, at 1506.

143. Id.

144. The classic statement is found in Chicago Board of Trade v. United States, 246 U.S. 231 , 238 (1918), where the Court stated that intention is relevant "not because a good intention will save an otherwise objectionable regulation or the reverse; but because knowledge of intent may help the court to interpret facts and predict consequences.'

145. See P. AREeda, supra note 48 , at $\ 1506$. 
purpose is not relevant in a horizontal price/fixing case, for example, because the inference of adverse effects is compulsory.

Purpose is often relied upon in evaluating agreements among competitors to which rules involving boycotts might be applied. ${ }^{146}$ The reason apparently lies in those rules themselves. Traditionally, boycotts have been described as per se violations, illegal without consideration of effects. ${ }^{147}$ Until very recently the definition of boycott, for the purpose of this rule, has been far too broad. ${ }^{148}$ Virtually any horizontal agreement can be characterized as a boycott. For example, a simple price-fixing agreement is a concerted refusal by the conspirators to deal with anyone who will not pay the fixed price. ${ }^{149}$ The characterization is immaterial, because such conduct is per se illegal anyway. But in cases involving joint ventures and trade and professional associations, application of a per se rule, focused more on means than effects, has jeopardized legitimate activities that have no adverse impact. ${ }^{150}$ Confronted with conduct that appears legitimate, and a rule that seemed to

146. See Kissam, supra note 139, at 1165, 1191-92; Bauer, Per Se Illegality of Concerted Refusals to Deal: A Rule Ripe for Reexamination, 79 Col. L. Rev. 685, 693-94 (1979). Statements that a boycott is per se illegal only when there is a purpose to exclude competitors or to carry out some other anticompetitive objective abound in decided cases. See, e.g., De Fillippo v. Ford Motor Co., 516 F.2d 1313, 1318 (3d Cir. 1975); Joseph E. Seagram \& Sons, Inc. v. Hawaiian Oke \& Liquors, Ltd., 416 F.2d 71, 76 (9th Cir. 1969), cert. denied, 396 U.S. 1062 (1970).

147. The most extreme statements of the rule are found in Silver v. New York Stock Exchange, 373 U.S. 34 1, 347 (1963); Klor's, Inc. v. Broadway-Hale Stores, Inc., 359 U.S. 207, 212 (1959). In Northwest Wholesale Stationers, Inc. v. Pacific Stationery \& Printing Co., 472 U.S. 284, 290 (1985), the Court recognized that it "has long held that certain concerted refusals to deal or group boycotts are so likely to restrict competition without any offsetting efficiency gains that they should be condemned as per se violations of $\S 1$ of the Sherman Act."

148. The formulation of the per se rule in Klor's, 359 U.S. at 212, literally encompasses any concerted refusal to deal. This would include a variety of activities of trade associations and joint ventures which are not anticompetitive. Virtually any agreement among firms concerning terms of sale or product can also be characterized as a concerted refusal to deal. For the variety of agreements to which the per se rule could be applied see P. AREEDA, supra note 48, at $\uparrow \rrbracket 385,390$. Much of the criticism of the rule has been directed to its breadth, and has been accompanied by proposals to narrow the rule in one fashion or another. See generally L. Sullivan, supra note 105, at 229-32; Heidt, Industry Self-Regulation and the Useless Concept "Group Boycott", 39 VAND. L. REv. 1507 (1986); Kissam, supra note 139; Bauer, supra note 146; Rahl, Per Se Rules and Boycotts Under the Sherman Act: Some Reflections on the Klor's Case, 45 VA. L. REv. 1165,1172 (1959). As put by Judge Robert Bork in Rothery Storage \& Van Co. v. Atlas Van Lines, Inc., 792 F.2d 210, 215 (D.C. Cir. 1986), cert. denied, 479 U.S. 1033 (1987):

Despite the seeming inflexibility of the rule as enunciated by the Court, it has always been clear that boycotts are not, and cannot ever be, per se illegal. To apply so rigid and simplistic an approach would be to destroy many common and entirely beneficial business arrangements.

These criticisms of the breadth and uncertainty of the formulation of the per se rule were acknowledged by the Court in both Northwest Wholesale Stationers, Inc. v. Pacific Stationery \& Printing Co., 472 U.S. 284, 294 (1985), and FTC v. Indiana Federation of Dentists, 476 U.S. 447 (1986).

149. See Rahl, supra note 148 , at 1172.

150. For example, application of a per se boycott rule whenever a trade association or joint venture enforces its standards through a denial of membership to competitors who fail to meet those standards threatens the legitimate and often procompetitive activities of such organizations. The Court's reformulation of the per se rule in Northwest Wholesale Stationers, Inc. v. Pacific Stationery \& Printing Co., 472 U.S. 284, 296 (1985), was in response to just such a concern. 
preclude consideration of effects, lower courts have avoided its application in a variety of ways. ${ }^{151}$ Some have done so by emphasizing purpose. ${ }^{152}$

The per se rule with respect to boycotts has been particularly troublesome in health care cases. Virtually any professional association rule which is enforced through a denial of benefits, such as staff privileges or accreditation, can be described as a boycott. ${ }^{153}$ Emphasis on purpose in health care cases of this type has added flexibility and mitigated the harshness of the per se rule. With the Supreme Court's reformulations of boycott doctrine in Northwest Wholesale Stationers, Inc. v. Pacific Stationery E Printing Co. ${ }^{154}$ and FTC v. Indiana Federation of Dentists, ${ }^{155}$ there is less need for such reliance on the parties' purposes. These decisions move in the direction of effects analysis. ${ }^{156}$ And in an antitrust policy whose sole concern is price and output effects, purpose serves only as evidence of effect.

A purpose to enhance or protect quality of care is thus relevant in only one of two ways. Evidence of such purpose may negate evidence of a purpose to injure competition, unless the demonstrated purpose is to improve quality by eliminating competitors. Furthermore, it is some evidence that the effect is

151. The Court of Appeals for the Seventh Circuit, for example, has confined the per se rule to cases in which a boycott is used "to enforce a rule or policy or practice that is itself illegal per se." Vogel v. American Soc'y of Appraisers, 744 F.2d 598, 600 (7th Cir. 1984). See also discussion in Heidt, supra note 148, at 1525-36. The rule has also been confined to cases involving agreements among competitors where the direct effect is upon firms competing at the same level. See, e.g., Lomar Wholesale Grocery v. Dieter's Foods, 824 F.2d 582, 590-591 (8th Cir. 1987), cert denied, $108 \mathrm{~S}$. Ct. 707 (1988); M \& H Tire Co., Inc. v. Hoosier Racing Tire Corp., 733 F.2d 973, 978 (Ist Cir. 1984). In Rothery Storage \& Van Co. v. Atlas Van Lines, Inc., 792 F.2d 210, 215-216 (D.C. Cir.), cert. denied, 479 U.S. 1033 (1986), the court seems to have limited the per se rule to boycotts that are "naked," i.e., not ancillary to a legitimate joint venture or other integration. Still other reformulations have been offered by commentators. See L. Sullivan, supra 105, at 24 I (per se rule should be confined to "explicit" boycotts); Bauer, supra note 146, at 717 (per se rule should be limited to those boycotts "where the parties intended to coerce or exclude another in order to lessen or eliminate some form of competition"); Heidt, supra note 148, at 1540-51 (urging tort law approach); Kissam, supra note 146, at 1194 (primary per se rule where boycott has a "dominant anticompetitive purpose").

152. See supra note 146. These cases use purpose to avoid application of a per se rule, and do not stand for the proposition that boycotts with demonstrable anticompetitive effects are lawful if done for a good purpose.

Purpose has also been relied on to avoid the application of the per se rule in other boycott cases involving professionals. See supra note 140 . But these cases rest on the view that professional activity warrants special treatment and do not necessarily represent standards applicable to boycotts generally.

153. See Havighurst \& King, supra note 11, at 174.

154. 472 U.S. 284 (1985).

155. 476 U.S. 447 (1986).

156. In Northwest Wholesale Stationers, the Court held that the per se rule did not apply to expulsion from a purchasing cooperative made up of plaintiff's competitors absent a showing that the cooperative "possesses market power or unique access to a business element necessary for effective competition." 472 U.S. at 298 . Without such a showing, a court could not find that the expulsion was per se illegal. Id. The Court also noted that in prior cases in which it had applied a per se rule. the practices were not justified "by plausible arguments that were intended to enhance overall efficiency." Id. at 294. The meaning of Northwest Wholesale Stationers is unclear. Would a per se rule apply to an expulsion if the venture possessed market power even if efficiency justifications are clear? One would think not. This is not a naked restraint. But whatever the answer, the Court's emphasis on market power is consistent with an effects analysis. The boycott analysis in Indiana Federation of Dentists is similar, although qualified by the observation that "we have been slow to condemn rules of professional associations as unreasonable per se." 476 U.S. at 458. 
likely to be as the parties intend. Even in this limited role, evidence of purpose is not likely to be particularly helpful. Purpose is notoriously difficult to ascertain. ${ }^{157}$ The same person or organization may have mixed motives. One might act to increase both efficiency and price, or to injure competitors and provide better care to the public. When multiple actors are involved in the alleged violation, each may act with a single purpose, but their purposes may differ. The identification of a single or dominant purpose may itself be sufficiently complex that such a judicially found purpose is totally unreliable as any indicator of likely effect.

Purpose is of limited relevance in an evaluation of price and output effects, even where its proof is clear. The intention to protect the public health, or the quality of care provided to particular patients, cannot justify conduct whose adverse impact is demonstrated or inferable from the conduct itself. Such a worthy purpose, even if proven, is in no sense a defense. And it is unlikely in most cases that conduct inviting antitrust attack is motivated solely by such purpose in any event. ${ }^{158}$

f. The structure of analysis-balancing and less restrictive alternatives. While there is no single quality-of-care defense in consumer welfare analysis, contentions about quality that are predicated on corrections of market failures, more efficient use of resources, protection of reputation for quality, and, to a limited extent, intention may in appropriate cases be relevant in determining competitive effect. But what weight are such factors to be given? How are they to be taken into account? Can and should an analysis be structured in some fashion, or should judges (and juries) simply be instructed to take all facts into account?

These are not new questions. Courts and commentators have struggled for decades to devise an analytic structure that would consider such factors in an ordered and logical fashion. ${ }^{159}$ The ancillarity test adopted in United States v. Addyston Pipe $\mathcal{E}$ Steel Co., ${ }^{160}$ for example, is designed to work an accommodation between adverse competitive effects and efficiencies achieved through integrations (or partial integrations) of competing firms. ${ }^{161}$ Where the restraint is naked, that is, related to no efficiency gain other than that which may be accomplished by reducing competition, it is condemned. Conversely, where the restraint accompanies an integration that is not itself objectionable and is likely to enhance competition, it is tolerated if it is

157. See 7 P. Areeda, supra note 48, at 1 1506. Professor Kissam, in proposing a "purpose-based" standard for boycott cases, defines purpose as a "construct about the plausible goals of rational actors," an objective conclusion drawn in part from an examination of power and effect. Kissam, supra note 139, at 1182 . While such a standard does not encounter all of the proof difficulties inherent in proving actual purpose, it is in essence a power and effect test, a kind of structured rule of reason in which anticompetitive effects and efficiency gains need not be balanced against each other once the predominating "purpose" is determined.

158. See, e.g., Leibenluft \& Pollard, supra note 38, at 953, 960.

159. For more detailed discussions, see Sullivan, supra note 82; Kauper, Comment: The Sullivan Approach to Horizontal Restraints, supra note $\mathbf{8 2}$.

160. 85 F. 271 (6th Cir. 1898) (Taft, J.), modified and aff'd, 175 U.S. 211 (1899).

161. See R. BORK, supra note 14, at 26-30. 
reasonably necessary to the integration. Per se rules likewise rest on such an accommodation. They are appropriate only for conduct that in virtually all cases has significant adverse price and output effect and little likelihood of promoting efficiencies. ${ }^{162}$ More recently, such accommodation has been sought through the development of a structured rule of reason. ${ }^{163}$

Analysis must begin by asking whether the conduct at issue has had, or is likely to have, adverse price and output effects. If such effects could be directly measured, the inquiry would end. But in few cases can this be done, and in even fewer can it be done efficiently within the judicial process. As a result, inferences must be drawn from conduct and the market power of the firms involved.

Per se treatment without examination of power is appropriate in those cases where the conduct is almost invariably output-restricting, seldom efficiency-creating, and where a bright line rule is necessary for deterrence purposes. In recent years, the use and scope of per se rules has been sharply restricted. Horizontal price-fixing and market division remain per se illegal, ${ }^{164}$ and should remain so as long as confined to cartel behavior. These rules are as applicable to health care markets as others. Tying arrangements are subject to what is still described as a per se rule, which in reality is not. ${ }^{165}$ There is every indication that tying arrangements may be justified in reputational terms, ${ }^{166}$ a justification not peculiar to health care markets. The per se rule against boycotts is being contracted and modified to focus on the legitimacy of the underlying agreement which is carried out through the refusal to deal. ${ }^{167}$ While the boycott rule has been particularly troublesome in health care cases, it is troublesome for reasons applicable to other markets as

162. See Broadcast Music, Inc. v. Columbia Broadcasting Sys., 441 U.S. 1, 9 (1979) (per se rule appropriate if practice is "plainly anticompetitive" and without "redeeming virtue"); Continental T.V., Inc. v. GTE Sylvania Inc., 433 U.S. 36, $49-50$ (1977) (similar).

163. See 7 P. AREedA, supra note 48, at I 1511; Kauper, supra note 82, at 901, 905-15; Sullivan, supra note 82, at 838-55. Compare Easterbrook, The Limits of Antitrust, 63 TEX. L. REv. 1, 14-39 (1984) (suggesting a set of "filters" to be used in antitrust analysis), with Fox, The Politics of Law and Economics in Judicial Making: Antitrust As a Window, 61 N.Y.U. L. Rev. 554, 567-76 (1986), and Markovits, The Limits to Simplifying Antitrust: A Reply to Professor Easterbrook, 63 TEx. L. REv. 41, $76-86$ (1984) (both criticizing Easterbrook's approach, albeit on quite different grounds).

164. See, e.g., Catalano, Inc. v. Target Sales, Inc., 446 U.S. 643, 647 (1980) (horizontal price-fixing illegal per se); United States v. Topco Associates, Inc., 405 U.S. 596, 608 (1972) (same for horizontal market division).

165. In Jefferson Parish Hosp. Dist. No. 2 v. Hyde, 466 U.S. 2 (1984), the majority and concurring Justices disagreed over whether the per se categorization should apply to tying arrangements, which have long been so characterized. See, e.g., Northern Pac. Ry. Co. v. United States, 356 U.S. 1, 5 (1958). Whatever one's views on this verbal disagreement, the important point is that such arrangements are illegal per se only if the seller has market power (presumably more than $30 \%$ of the market in the tying product) or that product is otherwise unique. See Hyde, 466 U.S. at 13. This version of the per se rule is a far cry from the per se rule applied in horizontal price-fixing cases, where market power is irrelevant. See United States v. Socony-Vacuum Oil Co., 310 U.S. 150, 224.26 n.59 (1940). Recognition of a "goodwill" defense (see supra note 127) and the possible willingness to permit tying arrangements as market entry devices, Hyde, 466 U.S. at 23-24 n.39, are also inconsistent with the per se analysis of Socony-Vacuum. The analysis applied in tying cases is best described as a structural rule of reason.

166. The goodwill defense protects reputation.

167. See supra notes 149, $150,156$. 
well. To the extent the rule is not based on effects, it is inconsistent with consumer welfare analysis as applied in any market. The determination that a per se boycott rule is appropriate in a health care case is no different than in any other.

In cases not subject to a per se rule, analysis must begin with whether the conduct could have adverse price and output effects. If the parties lack market power, such effects cannot be likely, and the case should be dismissed. The examination of market power is therefore the next step. ${ }^{168}$

Where these two preliminary criteria are satisfied, more detailed examination of effects and justifications will be necessary. Market failure considerations now become relevant in the effects analysis, to determine whether inferences drawn from such conduct in markets not characterized by such failure are appropriate in this instance. Allegations of failure may not be established. The conduct in question may have little to do with correcting the failure. Efficiencies claimed may be nonexistent or trivial. Reputational effects may be slight, or the actions taken not reasonably related to the reputational harm asserted. In such cases, these alleged justifications can be ignored.

Where on its face the parties' conduct is likely to have adverse price and output effects, and efficiencies or the need to guard against reputational harm are established, these procompetitive effects need not be considered in the analysis if they can be achieved in a reasonable, less restrictive way. The availability of less restrictive alternatives suggests that the parties' purpose is broader than achieving that which they could do equally well without the restraint. And society ought not bear the burdens of output-restricting conduct when such conduct is not necessary to achieve the benefit alleged.

The rejection of justifications because less restrictive means to the same end are available is well-established in antitrust doctrine. ${ }^{169}$ But care must be taken in applying such a reasonable alternatives test. It can too easily become a way of second-guessing legitimate business judgments with the benefit of hindsight. Justifications should not be rejected because bright lawyers at trial suggest an alternative which might have been available. Alternatives, for this purpose, must be reasonable and relatively obvious. ${ }^{170}$

Only the hard cases will survive the analysis to this point. These are cases where the conduct may create or use market power to restrict output, and simultaneously promote productive efficiencies or enhance reputation. In such cases, courts and commentators often speak of balancing pro- and

168. See Kauper, supra note 82, at 905-08. Market power is not a necessary step if antitrust must account for values other than economic efficiency.

169. See NCAA v. Board of Regents, 468 U.S. 85, 114-15, 119 (1984). The Court's rejection of the goodwill defense in a number of tying cases has rested squarely on an evaluation of less restrictive alternatives. See supra note 118. For health care cases resting, in whole or in part, on consideration of less restrictive alternatives see, e.g., Kreuzer $v$. American Academy of Periodontology, 735 F.2d 1479, 1495 (D.C. Cir. 1983); Wilk v. American Medical Ass'n, 671 F. Supp. 1465, 1483 (N.D. Ill. 1987). Fuller discussions may be found in 7 P. AReeda, supra note 48, at $\$$ 1505 a; Kauper, supra note 82 , at $908-09$.

170. See Kauper, supra note 82 , at 909. 
anticompetitive effects. ${ }^{171}$ Balancing assumes that such effects are not only identified but quantified, a relatively hopeless task. ${ }^{172}$ Purpose, if demonstrable, may be useful as a guide at this point. Because of the difficulty in identifying efficiencies and quantifying not only efficiencies but price and output effects as well, some have suggested that there be no consideration of fact-specific efficiencies at all. ${ }^{173}$ Outcomes would depend solely on the output-restricting consequences of conduct, measured through use of economic theory. While others have suggested that such a balance may be drawn in some cases, ${ }^{174}$ it may well be that the best that can be expected is judgment about predominant effects based on informed intuition.

2. Beyond Consumer Welfare: Quality of Care in a Multi-Valued Antitrust Policy. The discussion to this point has assumed that antitrust policy is concerned solely with economic efficiency. But whether this is so is the subject of ongoing debate. ${ }^{175}$ Moreover, the reservations about professional activity expressed in Goldfarb and repeated in various reformulations subsequently may suggest that even if antitrust policy generally is confined to an analysis of price and output effects, professions are to be treated differently. If so, the Court must mean that goals other than economic efficiency must somehow be accommodated, and quality-of-care concerns might be treated differently than under the consumer welfare model.

Some contend that while antitrust policy incorporates the goal of efficiency, it also encompasses a variety of other values from the political and social effects of corporate size to "fairness" in the marketplace. ${ }^{176}$ The issue will not be resolved here. However, would incorporation of this broader set of values result in greater, or lesser, recognition of quality-of-care claims? The answer turns on the values incorporated and their place in the appropriate analysis.

Generally, the inclusion of values such as redistribution of income, freedom from coercion, the preservation of small business, and so on results in an expansion of the definition of "anticompetitive." For example, conduct which "coerces" others would be condemned even if not likely to have

171. See, e.g., 7 P. AREeda, supra note 48, at I 1507; Graphic Prod. Distrib., Inc. v. Itek Corp., 717 F.2d 1560, 1571 (1 l th Cir. 1983); Smith v. Pro Football, Inc., 593 F.2d 1173, 1183 (D.C. Cir. 1978); Vuciecevic v. MacNeal Memorial Hosp., 572 F. Supp. 1424, 1429 (1983).

172. See Kauper, supra note 82 , at 899, $900,911-13$.

173. See, e.g., R. Bork, supra note 14, at 123-29.

174. 3 P. Areeda \& D. Turner, Antitrust Law, supra note 138, at 9ף 948-60 (possible efficiencies defense in merger cases); Williamson, Economies as an Antitrust Defense: The Welfare Tradeoffs, 58 AM. Econ. REv. 18 (1968) (discussing viability of economics defense).

175. See supra note 82 .

176. See, e.g., Fox, supra note 163, at 562-67 (antitrust encompasses range of economic and other values); Fox, The Modernization of Antitust, supra note 82, at 1146-55 (same); Pitofsky, The Political Content of Antitrust, 127 U. PA. L. REv. 1051, $1052-58$ (1979) (antitrust incorporates broad range of political values); Sullivan, Economics and More Humanistic Disciplines: What are the Sources of Wisdom for Antitrust?, 125 U. PA. L. Rev. 1214, 1232-41 (1977) ("humanistic" goals are part of the antitrust process). 
adverse price and output effects. ${ }^{177}$ These values are employed to justify greater antitrust intervention, not less. ${ }^{178}$ Antitrust policies reflecting such values might therefore pose an even larger, and more genuine, risk to quality of care, simply because in more cases anticompetitive effects would be found. If the denial of staff privileges is anticompetitive because it is somehow unfair to the complaining physician, more of these cases are likely to result in liability than if the likelihood of adverse price and output effects must be established. Even per se treatment under the rule against boycotts could be justified on the grounds of such "unfairness."179 The relevance of quality-ofcare concerns in such an analysis is not clear. The treatment of quality concerns applicable under the consumer welfare standard, which focuses solely on price and output effects, would not be appropriate. If coercion is grounds for antitrust liability only when price and output effects are unclear and no efficiencies are created, as some contend, ${ }^{180}$ improvement of quality might be sufficient to offset the coercion claims. If restraints that coerce or impair a way of economic life more in accord with a populist philosophy are to be condemned without regard to efficiency, as has sometimes been suggested, ${ }^{181}$ why is there reason to believe that a quality-of-care defense is any more cognizable than the promotion of efficiency?

The argument for a broad quality-of-care defense based on a variety of non-economic factors, or economic factors other than those employed in consumer welfare analysis, further assumes that such values can be used to justify private restraints with adverse competitive effects. While there is precedent for affirmative use of antitrust to combat coercion, ${ }^{182}$ or to preserve opportunities for small businesses, ${ }^{183}$ there is little precedent for permitting private enterprises to impose restraints to the same ends. ${ }^{184}$ Such

177. See Pitofsky, Antitrust in the Next 100 Years, 75 Calif. L. REv. 817, 827 (1987); Sullivan, supra note 82 , at $848-53$

178. In addition to articles cited supra note 176, see Fox, Consumer Beware Chicago, supra note 82; Pitofsky, supra note 177, at 818-23, which make clear that the objection to an antitrust policy focused solely on efficiency is that it is not sufficiently interventionist.

179. See, e.g., Kissam, supra note 139, at 1197-1202 (espousing a "secondary per se rule" where self-regulation does not comply with procedural due process). Professor Kissam rests his analysis on a broad reading of Silver v. New York Stock Exch., 373 U.S. 341 (1963). Silver, however, has now been limited to cases where there is a federal statutory mandate for self-regulation. Northwest Wholesale Stationers, Inc. v. Pacific Stationery \& Printing Co., 472 U.S. 284, 291 -293 (1985) ("If the challenged action would not amount to a violation of $\S 1$, no lack of procedural protections would convert it into a per se violation because the antitrust laws do not themselves impose on joint ventures a requirement of process.'). See also Moore v. Boating Indus'y Ass'n, 819 F.2d 693, 695-696 (7th Cir.), cert. denied, 108 S. Ct. 160 (1987).

180. See, e.g., Sullivan, supra note 82 , at $849-54$.

181. See Brown Shoe Co. v. United States, 370 U.S. 294, 344 (1962) (Clayton Act); United States v. Aluminum Co. of Am., 148 F.2d 416, 429 (2d Cir. 1945) (Sherman Act).

182. See, e.g., Simpson v. Union Oil Co., 377 U.S. 13, 21 (1964).

183. See, e.g., United States v. Von's Grocery Co., 384 U.S. 270, 274-75 (1966); Klor's, Inc. v. Broadway-Hale Stores, Inc., 359 U.S. 207, 213 (1959). See generally Kauper, The Warren Court and the Antitrust Laws: Of Economics, Populism and Cynicism, 67 Mich. L. Rev. 325, 331-34 (1968).

184. The decisions in Chicago Board of Trade v. United States, 246 U.S. 231 (1918), and Appalachian Coals Co. v. United States, 288 U.S. 344 (1933), might be thought to be decisions permitting otherwise anticompetitive private restraints because small businesses were benefitted. But so interpreted these decisions are aberrational. More commonly, those urging a multi-valued 
justifications in effect delegate responsibility for accommodation of these values to the private sector, in circumstances where private action would otherwise violate the antitrust laws. A common objection to a multi-valued antitrust policy is the degree to which it requires courts to make political decisions, balancing social and economic values without legislative direction. ${ }^{185}$ Placing responsibility for such decisions in the hands of those whose economic interests are directly at stake and have reason to manufacture such justifications is even more objectionable and is not in the tradition of antitrust policy. ${ }^{186}$

However, assume otherwise. What values are protected through a qualityof-care defense that transcends the bounds of economic efficiency? Those who advocate a multi-valued antitrust policy find such values in its traditions. These values are familiar and include freedom of opportunity, freedom from coercion, protection of small business, redistribution of income, and amelioration of social and political harms caused by corporate concentrations. None of these concerns relate directly to quality of care or public health and safety. Antitrust tradition, even if multi-valued, provides no source for or guide to the development of such a defense.

There is, however, a tradition of self-regulation by professionals in general, and health care professionals in particular. It is to this tradition that some might turn to support a broad quality-of-care defense, either by including values drawn from this tradition among those which a multi-valued antitrust should accommodate, or by developing a special set of rules for the professions. The latter. approach builds upon the suggestion in Goldfarb that professional activities might warrant "different" treatment.

Reliance on this tradition has an obvious appeal. Self-regulation ${ }^{187}$ of the professions has a long history. ${ }^{188}$ Deference to the tradition of self-regulation enables judges to leave the resolution of quality issues to those who provide medical services and are presumably knowledgeable, rather than making complex decisions about quality themselves.

Self-regulation that does not have adverse price and output effects is consistent with consumer welfare analysis. The elimination of deception and the provision of information that informs decisions about quality/cost tradeoffs is procompetitive, improving the performance of markets. Self-

antitrust policy object to such restraints precisely because they delegate decisionmaking authority to private enterprises. See Pitofsky, supra note 176 , at 1056.

185. See R. Bork, supra note 14, at 89-93.

186. See, e.g., Fashion Originators' Guild of Am. v. FTC, 312 U.S. 457, 465 (1941) (pattern of selfregulation objectionable in part because "the combination is in reality an extra-governmental agency" which "trenches upon the power of the national legislature").

187. Self-regulation in this context refers to something more than voluntary standard setting, which is common in a variety of industries. I refer here to a pattern of self-determined rules enforced through sanctions imposed by the profession itself. In their severest form, these sanctions may preclude those not complying with these rules from entering or remaining in the profession. Such self-regulation may in some instances be directly authorized by the state.

188. See Rubin, The Legal Web of Professional Regulation, in Regulating the Professions 29, $31-35$ (R. Blair \& S. Rubin eds. 1980). 
regulation may in some instances be the most efficient way to avoid deception and provide consumers with the accurate information they need to make correct decisions on their own interest. ${ }^{189}$ If this is so, those engaged in selfregulation must be given the range of discretion necessary to carry out these functions. Competitive restraints reasonably ancillary to the achievement of these procompetitive ends should be legitimate.

The critical issue here is whether the tradition of self-regulation should be further accommodated within antitrust doctrine to permit restraints that do have adverse competitive effects but are motivated by a desire to safeguard quality of care. Despite the appeal of doing so, antitrust cannot accept selfregulation simply because it has been a long-standing tradition. Professional associations have relied on the sanctity of self-regulation, for example, to justify price-fixing. ${ }^{190}$ Yet no one would contend that such self-regulation is legitimate today. The pattern of such regulation developed long before the professions were subjected to the antitrust laws. Blind deference to selfregulation as it has existed in the past will simply undo the decision to apply the antitrust laws at all. It is a conscious decision to maintain the status quo. Yet there are no standards for accommodating some parts of this tradition to the exclusion of others. ${ }^{191}$ Is there, for example, a reasoned basis for distinguishing self-regulation directed toward patient care from that targeted at working conditions or professional image? While distinctions might be drawn on the basis of public, as opposed to private, benefit, or by reference to some traditional core of ethical principles, nothing in antitrust's tradition provides a basis for doing so. These are, in the end, political judgments.

Finally, the claim of a broad patient care defense, whatever its source and whatever its boundaries, raises two further questions. First, does such a defense rest on proof that the action in question will in fact improve quality, or upon a motive to do so? A judicial determination of actual quality effects is likely to be impossible, for reasons already discussed. Those who would advocate such a defense will almost invariably be led to suggest that it is the purpose of enhancing quality that is critical, despite all the vagaries inherent in its determination. Professional self-regulation with such a purpose is to receive some special recognition by an antitrust court. ${ }^{192}$

\section{See supra note 107.}

190. See, e.g., Goldfarb v. Virginia State Bar, 421 U.S. 773 (1975).

191. Professionalism encompasses a broad range of values and ideals which professional selfregulation may be intended, in whole or in part, to foster. Among these are a belief that professionals have skills and knowledge not shared by others which, in turn, suggests that the public is best served if they regulate themselves; the need to assure the trust and confidence of clients and the public at large; a sense that because of their particular expertise professionals have special responsibilities which in some cases conflict with financial motives; and a strong sense of professional autonomy and solidarity. See Kissam, supra note 41, at 5-10.

192. Such special recognition of the traditions of professionalism, including quality of service, could take one of several forms. Conduct believed to represent such traditions could be held to be outside the antitrust laws altogether. This approach is reflected in Cooper v. Forsyth County Hosp. Auth., Inc., 789 F.2d 278, 282 n.14 (4th Cir. 1986); Wilk v. American Medical Ass'n, 719 F.2d 207, 227 (7th Cir. 1983), cert. denied, 467 U.S. 1210 (1984) (discussed in detail infra text at notes 190-200). Or recognition of these traditions could lead a court not to apply an otherwise applicable per se rule 
Second, assuming that antitrust is to extend such special recognition, how is it to do so? Unless the conduct has adverse consumer welfare effects, there is no reason to consider the question. If it does, are these effects somehow to be balanced against quality improvement effects? The issue is even more complex if the quality-of-care defense, derived from some mixture of efficiency and social values, rests on purpose. Purpose is of some limited relevance even in consumer welfare analysis, as noted. To go beyond that assumes that a patient care purpose overrides a showing of adverse competitive effects. ${ }^{193}$ Effects cannot be balanced against purpose. Presumably price-fixing for the avowed purpose of enhancing quality will not be tolerated. The purpose criterion then must be more narrowly defined to include only conduct that has as its purpose improvement of care through means other than direct elimination of competition among those employing the restraint. Such a defense would be confined to cases where the adverse competitive effects are unintended and incidental, and has little to do with whether quality is actually enhanced or protected against debasement. Because it does not, there is insufficient public benefit to warrant such an absolute defense.

The strongest argument in favor of a patient care defense, which transcends consumer welfare analysis, is that the Supreme Court has itself recognized it. The observation in Goldfarb that because of "the public service aspect and other features of the professions," conduct by professionals that in other contexts would violate the law might "be treated differently,"194 bolstered by the references in Maricopa to "public service or ethical norms," 195 can be read as a direction to accommodate values derived from the tradition of professional self-regulation in some wholly undefined way. The Court's definition of "public service" and the particular standards of professional groups that it would term "ethical norms" are not clear. Obviously the label put on conduct by the actors themselves is not determinative. The restraint held unlawful in Professional Engineers was contained in a code of "ethics." The touchstone could be a non-commercial purpose. ${ }^{196}$ Or one may be required to identify, through the use of history and tradition, a core of professional standards that may fairly be described as

to some forms of professional self-regulation. See, e.g., FTC v. Indiana Fed'n of Dentists, 476 U.S. 447, 458 (1986) ("[W]e have been slow to condemn rules adopted by professional associations as unreasonable per se."); Weiss v. York Hosp., 745 F.2d 786, 820-21 (3d Cir. 1984); Kaczanowski v. Medical Center Hosp. of Vt., 612 F. Supp. 688, 693-694 (D. Vt. 1985); Pontius v. Children's Hosp., 552 F. Supp. 1352, 1369-370 (W.D. Pa. 1982). An unwillingness to apply a per se rule (particularly with respect to boycotts) in the setting of professional self-regulation is better explained in terms of the peculiarities of the markets for professional services. See Kreuzer v. American Academy of Periodontology, 735 F.2d 1479, 1492 (D.C. Cir. 1984).

193. As was held in Wilk, 719 F.2d at 227, discussed infra at note 200.

194. 421 U.S. at 788 n.17.

195. 457 U.S. at 349 .

196. Reliance on non-commercial purpose thus would be appropriate in cases involving professional self-regulation even though inappropriate in antitrust analysis more generally. See supra notes $140,152$. 
dealing with issues of ethics. ${ }^{197}$ Assuming that such lines can be drawn, are such norms simply outside the antitrust laws, or is some balance to be drawn? The Court does not say.

That Goldfarb can be read in this manner does not mean that it should be. The Supreme Court has never held that any professional self-regulation warrants particular dispensation from the antitrust laws. No cases in the Court have turned on the Goldfarb footnote, which has been consistently distinguished away. The broad interpretation just suggested is fraught with doctrinal and practical difficulties and would require judges to make broad political and social judgments of the type the Court in recent years has thought inappropriate in antitrust cases. ${ }^{198}$ The Goldfarb reservation can, and should, be read as nothing more than recognition that markets for professional services may differ from others in ways that are relevant in determining competitive effects. ${ }^{199}$ The reformulation of the Goldfarb footnote in Professional Engineers says precisely that. Inadequacy of information, for example, is a common feature of these markets. Public service and ethical norms deal, in large part, with problems of information, deception, or abuse of clients in the choices they are required to make. Professional standards that remove these imperfections can be upheld even under a consumer welfare analysis without distorting antitrust to create a special set of rules for professions.

\section{III}

\section{Translating Theory Into Reality: A Case Study}

This section examines two decisions, Wilk v. American Medical Association 200 and Koefoot $v$. American College of Surgeons, ${ }^{201}$ in which the boundaries of a quality-of-care, or patient care, defense, if any, are explored in depth. In both cases, the defendants placed primary reliance on the legitimacy of their efforts to guard the public in general, and their own patients in particular, against what, in their perception, was a significant threat to the quality of care provided. No other decisions discuss the issue as carefully or exhaustively. Both cases illustrate the practical difficulties confronting judges and juries

197. The Court in Goldfarb and Maricopa gave no hint of how "public service" or "ethical norms" were to be defined. In Koefoot v. American College of Surgeons, 652 F. Supp. 882, 888 (N.D. Ill. 1987), the court defined "facially legitimate ethical canons" as "rules of professional practice which, on their face, establish professional standards of care without reference to the economic interests of the professionals." More commonly courts have referred to such norms as though they know them when they see them, without further explanation. See, e.g., Weiss v. York Hosp., 745 F.2d 786, 821 (3d Cir. 1984).

198. See, e.g., Continental T.V., Inc. v. GTE Sylvania Inc., 433 U.S. 36, 53 n.21 (1977) ("an antitrust policy divorced from market considerations would lack any objective benchmarks").

199. Accord Blumstein \& Sloan, supra note 6; Havighurst \& King, supra note 11, at 170 n.124; Sullivan \& Wiley, supra note 41 , at 322-26.

200. 719 F.2d 207 (1983), cert. denied, 467 U.S. 1210 (1984). Following reversal by the court of appeals, the case was retried in a bench trial. Wilk v. American Medical Ass'n, 67I F. Supp. 1465 (N.D. Ill. 1987).

201. 652 F. Supp. 882 (N.D. Ill. 1987). A prior decision on a partial summary judgment motion appears at 610 F. Supp. 1298 (N.D. Ill. 1985). 
when such claims are asserted and they are called upon to evaluate conflicting scientific claims. Wilk is a decision of the court of appeals. The district court in Koefoot, governed by the decision in Wilk, was pressed to pursue its implications while not departing from it. The cases reflect not only theory, but the translation of that theory into the reality of the courtroom.

The three sections that follow consider Wilk and Koefoot in legal terms and then apply the consumer welfare analysis described above to both.

A. Wilk

In Wilk, plaintiff chiropractors asserted that the American Medical Association and its members conspired among themselves and with other groups including the American Hospital Association, American College of Surgeons, American College of Physicians, American College of Radiology, American Academy of Orthopedic Surgeons, and the Joint Committee on Accreditation of Hospitals ("JCAH") to conduct a nationwide boycott of chiropractic providers. ${ }^{202}$ While the facts are complex, the central feature of the alleged boycott was a 1966 AMA resolution stating:

It is the position of the medical profession that chiropractic is an unscientific cult whose practitioners lack the necessary training and background to diagnose and treat human disease. ${ }^{203}$

The effect of this resolution must be judged in the context of Principle 3 of the AMA's Principles of Medical Ethics, which states that "a physician should practice a method of healing founded on a scientific basis" and should not "voluntarily professionally associate with anyone who violates this principle." In 1969, the AMA issued an opinion that it was unethical for a physician to associate professionally with chiropractors. ${ }^{204}$ Over time, this view was circulated to a number of other medical groups. At the AMA's urging, JCAH, seven of whose twenty-one members are appointed by the AMA, adopted a provision similar to the AMA's 1966 resolution. ${ }^{205}$ Other groups followed the AMA's lead. During this period chiropractic was licensed in all fifty states, and such services were reimbursable under Medicare, Medicaid, and most private insurance plans. As providers of one form of health care, chiropractors compete with each other and with some physicians in the treatment of musculoskeletal problems.

The effect of the actions of the AMA and its co-conspirators was to discourage cooperation between chiropractors and physicians in the form of referrals, consultations, and the sharing of clinical and research results, and to deny chiropractors hospital facilities, including $x$-ray and laboratory facilities. Demand for chiropractic services was adversely affected, and the costs of chiropractors increased. ${ }^{206}$

202. 719 F.2d at 211 .

203. Id. at 213 .

204. Id.

205. Id. at 214 .

206. The district court so found. 671 F. Supp. at 1479. 
Throughout the litigation, the defendants insisted that they had acted to protect the public health and safety from what they believed to be a form of quackery, a type of treatment without foundation in science. This defense was the focal point of much of the evidence introduced at the initial trial in which defendants won a jury verdict, and at a second trial following reversal of the initial verdict by the court of appeals. As the court of appeals put it:

\section{[M] uch of the trial, and virtually all of the parties' arguments to the jury were a free- for-all between chiropractors and medical doctors, in which the scientific legitimacy of chiropractic was hotly debated and the comparative intensity of the avarice of the adversaries was explored. ${ }^{207}$}

The issue was presented to the appellate court on review of jury instructions at the first trial. The challenged instructions were lengthy, but provided in substance as follows: In order to find a per se violation, plaintiffs must show that the concerted refusal was "primarily or in large part for the purpose of excluding competitors" and that the primary motives of the defendants "were essentially commercial or economic in nature." Boycotts "of a non-commercial nature ..., ones that do not include among their principal aims the economic purpose of excluding competitors," are to be judged under the rule of reason. ${ }^{208}$

Under the rule of reason, "[o]ne of the factors to be considered" is whether the conduct had an adverse effect on competition, which in turn was described as a substantial effect in "preventing chiropractors from offering such services" as the law permits. It is "proper" for a professional association to formulate conduct standards because such standards benefit the public and insure that the profession merits public trust. In determining whether a professional standard violates the rule of reason, it is "necessary" to consider the "genuineness" of the justification, its reasonableness, its enforcement, and its effects. While the determination that chiropractors pose "an impermissible hazard" to public health is for legislative bodies and "cannot be overturned" by defendants, it is a "difficult question" whether doctors may limit their relationships with chiropractors "for the purpose of" complying with standards they deem desirable or necessary. Reasonable ethical principles "not aimed at" chiropractic may be lawful if they do not have a "significant and unnecessarily adverse effect" on chiropractors. In determining "the reasonableness of the defendants' purposes," consideration should be given to the "depth and sincerity of their beliefs" that a sharing of responsibility with chiropractors would pose "substantial hazards" to patients and the public welfare. ${ }^{209}$

Struggling with questions such as those already discussed in this paper, the trial court's instructions can be interpreted in a number of ways. The court of appeals found the per se instructions erroneous because the characterization of conduct as per se illegal does not turn on whether the actors' motives were

207. 719 F.2d at 216

208. Id. at 220 .

209. Id. at 222-23. 
primarily economic. ${ }^{210}$ The error was not prejudicial, however, because there was no evidence that would support a finding of per se illegality, for two reasons. First, under applicable precedent in the circuit, boycotts are per se illegal only when they are used to enforce underlying agreements that are themselves per se illegal.211 Second, given evidence of a "patient care" motive, per se treatment is inappropriate. ${ }^{212}$ Relying on Goldfarb's reservations, the court noted that an ethical standard dealing with the role of scientific method presented sufficiently novel questions to avoid per se analysis. ${ }^{213}$

These conclusions are striking by virtue of the juxtaposition of the holding that the per se instruction was erroneous because per se illegality does not depend on the presence of a primarily commercial motive and the conclusion that the conduct in question could not be per se illegal in any event in the presence of substantial evidence of a patient care motive. If this makes sense, it must be because a non-commercial motive and a patient care motive as defined by the courts are not the same. A patient care motive may be noncommercial, but a non-commercial motive does not necessarily relate to patient care. The court means precisely this, as its analysis of the trial court's rule of reason instructions indicates. ${ }^{214}$

The rule of reason instruction was erroneous because it treated adverse competitive effect as but one factor in determining the reasonableness of the agreement. Under Professional Engineers, the sole issue is whether the agreement promotes competition or suppresses it. Contrary to this standard, the trial court permitted the jury to consider the reasonableness of the AMA's standard, measured "in terms of values unrelated to free competition," above and beyond its assessment of competitive effects. Intent might be of some relevance in an examination of effects because an anticipated effect is perhaps more likely than an unanticipated one. The instructions, however, went beyond this "severely limited" function of an examination of intent. ${ }^{215}$

Had the appellate court stopped at this point, its analysis would have been fully consistent with conventional antitrust doctrine, given that defendants sought to justify their actions solely in terms of their purpose. But the court then concluded that in accord with Goldfarb's reservation it was free "to modify the rule of reason test in a case involving a certain kind of question of ethics for the medical profession."216 The Sherman Act is not indifferent to the value of permitting physicians to honor "what they perceive" to be "scientific method," and to uphold that method by not associating with those

210. Id. at 220.

211. See United States Trotting Ass'n v. Chicago Downs Ass'n, 665 F.2d 781, 787-790 (7th Cir. 1981) (en banc). The Seventh Circuit has continued to adhere to this view. See, e.g., Vogel v. American Soc'y of Appraisers, 744 F.2d 598, 600 (7th Cir. 1984).

212. 719 F.2d at 221 .

213. Id. at 226 .

214. Id. at 225-28.

215. Id. at 225 .

216. Id. at 225-26. 
who do not. In the court's words, "a value independent of the values attributed to unrestrained competition must enter the equation." 217 If the defendants' dominant motive was a concern over scientific method in the care of patients, their conduct was reasonable even if competition was restricted. Specifically, the jury should have been instructed as follows:

The burden of persuasion is on the plaintiffs to show that the effect of Principle 3 and
the implementing conduct has been to restrict competition rather than to promote it.
If the plaintiffs have met this burden, the burden of persuasion is on the defendants to
show: (1) that they genuinely entertained a concern for what they perceive as scientific
method in the care of each person with whom they have entered into a doctor-patient
relationship; (2) that this concern is objectively reasonable; (3) that this concern has
been the dominant motivating factor in defendant's promulgation of Principle 3 and in
the conduct intended to implement it; and (4) that this concern for scientific method in
patient care could not have been adequately satisfied in a manner less restrictive of
competition. 218

If these criteria are met, the conduct was not unreasonable. The instructions given, however, were not sufficiently precise and, in any event, failed to distinguish between a patient care motive and a public service motive. The latter, which the court describes as the intention to perform a public service by using economic pressure to curtail the threat chiropractic poses to public health, would not justify the restraint. While the patient care motive might justify the refusal of hospitals to associate with chiropractors in treatment of patients, economic warfare beyond that in the name of public service cannot. ${ }^{219}$

The court in Wilk thus avoids the need to balance social gains against the adverse effects caused by restraining competition. If defendants' conduct fell within the patient care motive, as described, the conduct was reasonable without regard to the magnitude of its price and output effects. Within narrow limits, the public benefits of self-regulation are to be preferred. Nor does its approach require courts to evaluate quality of care directly. By formulating its standard in terms of purpose, it is defendants' beliefs that are critical (constrained only by the requirement that those beliefs have a reasonable, objective basis). This is not a defense that rests on a determination that the public is benefitted because quality in fact improved.

Wilk rests squarely on the Goldfarb reservation, and is verbally inconsistent with consumer welfare analysis. At no point in fashioning its justification does the court attempt to evaluate the evidence presented by defendants in economic terms. With little guidance from the Supreme Court, and no roots in economic analysis, the court attempted with great care to formulate new standards of its own, consistent with what it perceived to be values drawn from a tradition of professional self-regulation. The distinction drawn

217. Id. at 227 .

218. Id. The court found that the jury was properly instructed on the applicability of the first amendment to the AMA's activities directed toward Congress, state legislatures, and state and federal administrative agencies, and was prepared to assume that the jury found all of its political activity protected. Id. at $\mathbf{2 2 8 - 3 0 .}$

219. Id. at 228. 
between the patient care and public service motives reflects the court's views as the core of traditional ethical concerns, the protection of the physicianpatient relationship. It also must be viewed as an effort to limit severely the scope of the justification, in recognition of the fact that the court was departing from what it itself described as the normal antitrust standard.

The public service/patient care distinction is hard to grasp. A refusal to associate with chiropractors may be justified by the patient care motive. The AMA's attempts to block licensing of chiropractors, however motivated by concerns over the public health, cannot be so justified (although such actions were within first amendment protection in any event). Yet by eliminating chiropractors the defendants would solve their associational concern. The distinction may well make sense in measuring effects. The adverse competitive effects are clearly greater if chiropractic is eliminated than if chiropractors are tolerated but handicapped. But the court did not put the distinction in such terms. The distinction becomes even more difficult once it is understood what was not at issue in Wilk. Plaintiff-chiropractors did not seek AMA membership. Nor did they in this litigation seek full hospital staff privileges. Nothing in the case implicates the right of a physician, or integrated unit of physicians, unilaterally to decline association with chiropractors. The right of a particular hospital to eschew such association was unquestioned. ${ }^{220}$ The issue was simply whether physicians could eliminate such association by agreement among otherwise independent units. It is the agreement, not the right of individuals to pick their own associates, which must be justified. The AMA action might provide information to physicians, informing their individual judgments. However, the alleged agreement went further. The agreement protected the relationship between a doctor and patient by assuring that others did not associate with chiropractors. If a patient care motive justifies such an agreement, it is because of a concern for the public generally.

Whether a jury, instructed as the court in Wilk directs, could understand these distinctions and solve the practical problems of identifying a dominant motive will not be learned from Wilk itself. On remand, the case was tried without a jury. The trial court concluded that while the defendants entertained a genuine concern for scientific method in the care of their patients and that this concern was the dominant factor motivating its actions, they failed to establish that as applied to chiropractors it was objectively reasonable. Moreover, the court was unconvinced that there were no less restrictive means to the same end. Specifically, the court saw no reason why an educational campaign would not achieve the AMA's desires. The patient care justification was therefore rejected.221

\footnotetext{
220. Furthermore, the court indicated that individual physicians, and "two or three" physicians providing services as a team, would be free to refuse association with particular chiropractors in treating individual patients. $I d$. at 226.
}

221. Wilk v. American Medical Ass'n, 67 I F. Supp. 1465 (N.D. Ill. 1987). 


\section{B. Koefoot}

Over half of all board certified surgeons in the country are members of the American College of Surgeons ("ACS"). ACS plays a significant role in board certification, and in the accreditation of hospitals. ${ }^{222}$ Three of twenty-one members of the Joint Committee on Accreditation of Hospitals are appointed by ACS. Board certification or status as an ACS fellow is required to hold staff privileges in hospitals accredited by JCAH. ACS also is involved in medical education and a variety of other activities. ${ }^{223}$

The "itinerant surgery" rule of the ACS prohibits:

[t]he performance of surgical operations (except on patients whose chances of recovery would be prejudiced by removal to another hospital) under circumstances in which the responsibility for diagnosis or care of the patient is delegated to another who is not fully qualified to undertake it. ${ }^{224}$

The effect of the rule is that ACS surgeons may delegate responsibility for post-operative care only to other surgeons.

Dr. Koefoot is a general surgeon who performs surgery in three hospitals in Grand Island, Nebraska, and in several community hospitals some twenty minutes away. He gives post-operative care to his patients in Grand Island, but delegates responsibility for such care to non-surgeon general practitioners in the community hospitals. After his expulsion from ACS for violating the itinerant surgery rule, he filed an antitrust suit against ACS, attacking the rule as a form of market allocation used by ACS members to block entry, as a boycott of non-surgeons, and as a tie-in between surgery and post-operative care. He was joined in his suit by three physicians to whom he delegated post-operative care and three hospitals where he performed surgery. ACS has defended the rule as a legitimate ethical canon adopted to enhance the quality of care provided surgical patients. ${ }^{225}$

Summary judgment in favor of defendants was denied. The rule on its face could work to protect local surgeons from the competition of visiting surgeons through refusals by local surgeons to provide post-operative care. In addition, the rule could eliminate competition between surgeons and nonsurgeons in post-operative care and injure competition between local and community hospitals. Evidence with respect to motive was in conflict.

At this writing, the case has not been tried. But in ruling on a series of motions in limine, the trial court held that the itinerant surgery violation was not a per se violation and set an agenda for the trial under the rule of reason. A "facially legitimate ethical canon," defined as a rule of professional practice that establishes standards of care "without reference to the economic interests of professionals," is not per se illegal. ${ }^{226}$

222. For example, ACS is a member of the Joint Commission on Accreditation of Hospitals

("JCAH"). See Wilk v. American Medical Ass'n, 671 F. Supp. 1465, 1490 (N.D. Ill. 1987).

223. Koefoot v. American College of Surgeons, 610 F. Supp. 1298, 1301 (N.D. Ill. 1985).

224. Koefoot, 652 F. Supp. at 884.

225. Id. at 887.

226. Id. at 888-89. 
The trial court then dealt with the relevance of evidence offered by ACS to establish (1) that their motive was to safeguard the quality of patient care, and (2) that the practice of itinerant surgery was in fact harmful. As to the first, the court found Wilk's patient care motive doctrine inapplicable, because ACS surgeons, other surgeons, and non-surgeons shared the same basic training and belief in scientific method.227 Moreover, while Wilk was not overruled by the later Supreme Court decisions in Jefferson Parish ${ }^{228}$ and Indiana Federation of Dentists, ${ }^{229}$ those decisions do suggest that any extension of Wilk would be improper. Motive evidence is relevant and admissible, but only for the limited purpose of evaluating effect. Evidence that itinerant surgery was in fact harmful is relevant only to establish ACS's intent. If the practice is harmful, it is somewhat more probable that patient care was ACS's motive. So proof of actual harm is some evidence of intent, which in turn is some evidence of effect. Because harm evidence is of limited relevance, and is a type of evidence that is likely to be prejudicial, the court concluded that its quality and quantity must be severely limited. ${ }^{230}$

In a second set of motions, ACS revived its efforts to focus the trial on the issue of harm to patients. ${ }^{231}$ Accepting the premise that the sole inquiry was anticompetitive effect, ACS recast its arguments in competitive terms. First, if the rule actually improves quality, it is procompetitive. This argument, which would apparently create a broad quality-of-care defense upon proof that the conduct prevented harm to patients, was rejected as inconsistent with the theory underlying Wilk. ${ }^{232}$ Second, ACS contended that ACS membership functions as a "seal of approval relied upon by consumers seeking a higher standard of patient care." To establish this procompetitive informational effect, ACS asserted that it was necessary to establish that itinerant surgery is actually harmful. Only if it is can the information be valuable to consumers. ${ }^{233}$

The court did not reject the information argument. The ACS membership label could enable consumers to find a desirable service more efficiently, and therefore be procompetitive. But whether care is actually improved is not the issue. ACS need only establish that consumers, for whatever reason, desire post-operative care by surgeons. If consumers prefer local hospitalization

227. Id. at 890-91.

228. Jefferson Parish Hosp. Dist. No. 2 v. Hyde, 466 U.S. 2 (1984).

229. FTC v. Indiana Fed'n of Dentists, 476 U.S. 447 (1986).

230. Koefoot, 652 F. Supp. at 896.

231. Following the trial court's initial rulings on a series of motions in limine, rulings which sharply restricted the ability of defendants to introduce evidence of harms to patients resulting from the practice of itinerant surgery, defendants filed a motion to "clarify" in which they again sought to expand the admissibility of such evidence. Opinions on both sets of motions appear together at 652 F. Supp. 882. It is hard to avoid the conclusion that defendants sought to use such evidence to unduly influence the jury. This was precisely what the district court was trying to avoid. See $652 \mathrm{~F}$. Supp. at 893.

232. Id.

233. Id. at 902 . 
without such care that is their choice to make. The market, "not judges, juries or even doctors," will determine the best care. ${ }^{234}$

The insistence by the court in Koefoot upon a singleminded inquiry into effect is consistent with consumer welfare analysis. Intention is relevant only as it illuminates effect.

Uncomfortable with the Wilk patient-care-motive justification, the court confined it to cases involving allegations of pure quackery. It is apparent that the court was determined not to make judgments about the medical consequences of itinerant surgery and feared that evidence about harm would distract the jury from its assignment to focus solely on competitive efforts. The court's opinions are clearly those of a trial judge trying to keep a trial within manageable bounds, and to translate a rather complex theoretical structure into the practicalities of presenting evidence. ${ }^{235}$

As part of the process of pre-trial preparation, the focus in Koefoot has narrowed down from the assertion of a broad quality-of-care defense to a focus on the informational effects of ACS membership. This, as we shall see, is where the focus should be. Wilk's patient care motive was a distraction, but only that.

\section{Consumer Welfare Analysis as Applied to Wilk and Koefoot}

With the exception of its recognition of the patient care motive, Wilk proceeds on the correct assumption that antitrust outcomes depend on an analysis of effects. While the court does not embrace the concept that antitrust is concerned solely with economic efficiency, nothing in its opinion suggests that it thinks otherwise. The same may be said of the opinions in Koefoot. The decisions are therefore consistent with the general pattern emerging from the Supreme Court's opinions in antitrust health care cases. ${ }^{236}$ Assuming that these decisions should be governed by the same consumer welfare analysis applied in all other antitrust cases, how are the principles already discussed to be applied?

The alleged adverse effects of the chiropractor boycott occurred through the refusal of physicians, radiologists, and hospitals to associate in any way with chiropractors. This refusal was not the result of individual, informed decisionmaking by separate units acting in their own economic interests. Rather, it was brought about by an agreement with which each was required to abide under the threat of discipline or denial of accreditation. ${ }^{237}$ On its face, the boycott did not affect price competition among physicians, among

234. Id. at 904. The court further noted that while learned professions may be somewhat different, in the Supreme Court "the balance has consistently gone to the side of free market choices." Id.

235. The court was particularly concerned that so-called "harm" evidence was likely to be prejudicial in a jury trial. 652 F. Supp. at 893.

236. See supra text at 281-92.

237. Apart from the agreement among its members reflected in the AMA's own activities, the trial court also found that the American Academy of Orthopaedic Surgeons and the American College of Radiologists were also participants in the conspiracy. Parallel actions by the JCAH and the American 
radiologists, or among hospitals, although it did eliminate competition within each of these groups for business through referrals or use of services by chiropractors. The primary effect was to increase the costs of chiropractors, and to otherwise handicap them in the delivery of services. ${ }^{238}$ Competition between chiropractors and physicians was significantly reduced. Consumers were deprived of a service they apparently desired. The trial court did not directly examine price and output effects, and it is not clear that it could have done so.239 It is not unreasonable to conclude that the elimination or handicapping of an alternative method of competition would have adverse effects within the market in which physicians and chiropractors actually competed. ${ }^{240}$

The itinerant surgery rule appears less likely to have adverse price and output effects. On its face, the rule prevents ACS from dealing with a group of physicians who might otherwise compete in providing post-operative care. It is this refusal to deal with a group of competitors who are not in the same specialty which creates at least a superficial resemblance between the conduct in Wilk and Koefoot and distinguishes these cases from a number of others.

Whether this refusal might have adverse effects will depend on a careful examination of market power and pricing structures within particular markets. ACS surgeons may lack power over price. ${ }^{241}$ Itinerant surgery may offer no cost advantages. Surgeons not providing post-operative care might be able to charge a higher price for surgery alone, with the result that the price to the consumer for the entire procedure might be unchanged. Other adverse effects are alleged. Competition between rural and metropolitan hospitals is allegedly reduced. Local surgeons are protected against visiting surgeons; all they need do is refuse to provide post-operative care. These effects cannot be inferred. For example, that the rule could be used to benefit local surgeons does not mean that it has been. Nor is it clear why surgeons would want a rule that makes it difficult for rural hospitals to compete.

College of Physicians were undertaken independently. 671 F. Supp. at 1471. Several other professional organizations named as defendants settled prior to trial.

Hospitals allowing use of facilities by chiropractors would "very probably" be denied JCAH accreditation, and hospitals acted accordingly. See 719 F.2d at 214 . While JCAH's standards were found to have been independently adopted, the threat of a denial of accreditation was well-known to the AMA and was a fact relevant in assessing the effects of the AMA's actions.

238. See 671 F. Supp. at 1479.

239. The trial court held that given the nature of the AMA's actions and its power in the market, specific proof of price and output effects was not required. Id.

240. In hospital staff privileges cases, for example, the only parties directly involved are those to whom staff privileges are denied; staff benefits are not generally conditioned upon the refusal of staff members to deal with third parties. The same is generally true in accreditation and certification cases. But in Wilk and Koefoot the rules under attack required non-dealing with others. In this respect, these cases more closely resemble classic, secondary boycott cases like Fashion Originators' Guild v. FTC, 312 U.S. 457 (1941). Cases involving secondary pressure have traditionally been particularly suspect. See, e.g., Heidt, supra note 148, at 1586-95.

241. Markets for general surgery services are presumably relatively local. Whether ACS surgeons have the ability to raise price significantly will rest to a substantial degree on the number of non-ACS surgeons in the market with access to surgical facilities. 
The rule does not adversely affect competition between ACS fellows and other surgeons, except to the extent ACS status is valued by purchasers of their services. Hospitals may prefer to extend staff privileges only to ACS fellows, but accreditation standards do not require them to do so. Consultation between ACS fellows and other surgeons is not prohibited. Board certified surgeons who do not follow ACS standards may actually have a competitive advantage over their ACS counterparts in their ability to make alternative arrangements for post-operative care. ${ }^{242}$

Assuming that the likelihood of adverse competitive effects is established in both cases, are there other economic factors relating to quality of care that might be presented in justification? Putting to one side Wilk's patient-caremotive defense, both Wilk and Koefoot relegate intent to its appropriate subordinate role. If adverse effects are established, intent is no longer relevant. The focus shifts, then, to issues of productive efficiency, generation of market information, and the enhancement of rivalry through product competition and reputation for quality.

In neither Wilk nor Koefoot is there any integration which might result in efficiencies in the delivery of specific services to consumers. In both cases, the setting of standards by a central professional group could reduce the costs that would otherwise be incurred by physicians and hospitals in securing information, although this seems more likely in Koefoot than in Wilk, as discussed below. What of reduction in potential liability costs, or costs of liability insurance? Physicians, radiologists, and hospitals who collaborate with or perform services for chiropractors might be held liable for misdiagnosis or faulty treatment that chiropractors provide. Chiropractors, as a class, might create a higher risk of liability than other groups with whom collaboration is permitted. Conceivably, surgeons' liability potential might increase if post-operative care is placed in the hands of non-surgeons. But such concerns, however justified, and however appropriate as the basis for individual decisionmaking, cannot justify agreements by entire medical specialties not to deal with such groups. Provision of information concerning liability risk should be sufficient to enable each provider to make its own affiliation decisions.

If the conduct challenged in these cases is procompetitive, it is because it provides information and advice, or enhances competition in terms of product or reputation as competitors seek advantages over their rivals. The district court in Koefoot perceived this point in focusing on the information value of the ACS "seal of approval." 243

Credentialing by professional groups enhances competition by supplying information and advice in markets where they are lacking. ${ }^{244}$ Those familiar

242. Just as Dr. Koefoot himself may have had such an advantage in using non-surgeons for postoperative care.

243. 652 F. Supp. at 904 .

244. See generally Havighurst and King, supra note 11, at 132-38; Kissam, supra note 41, at 60-65. Credentialing standards are often based more on opinions and beliefs than hard scientific fact. Professor Kissam has urged that the first amendment provides the basis for curtailing the application 
with ACS standards, for example, know without further inquiry that ACS fellows meet those standards. Others may rely on ACS credentials as a form of advice. While such information might be otherwise available, the credentials provide it at lower cost. Assuming that these credentials are competitively significant to those who possess them, and that they in fact represent legitimate concerns over medical care, such credentials provide incentives for those seeking them to improve their performance.

Adverse competitive effects cannot be found in the denial of such credentials alone. Credentialing those who do not conform to the standards adopted would dilute the meaning of the credentials and, in some cases, would be deceptive. ${ }^{245}$ The refusal to grant credentials is a necessary concomitant to any credentialing program. There is no less restrictive alternative apparent. The focus must be on the competitive effects of the rules themselves, not on the fact that they are enforced by denial or expulsion.

If credentials provide information consumers value, rightly or wrongly, they provide a competitive advantage to those possessing them. Professional associations such as ACS must be viewed as joint ventures, created and financed by members precisely because they obtain that advantage and enhance their position over their rivals. ${ }^{246}$ The incentive for the creation and continuance of such ventures rests in the desire of some to differentiate themselves from others. While those not possessing these credentials are in a sense harmed, they are harmed because consumers and others value the information such credentials provide. This harm is caused by the choices consumers make. It is not the result of any restraint, but of the competitive process itself. ${ }^{247}$

Credentialing is not always procompetitive. A credentialing standard which simply fixes prices or divides markets is not lawful. Other standards may so reduce competition among those within the association that the information they impart may be overborne by the price and output effects which result. ${ }^{248}$ But such effects must be sharply distinguished from the

of the antitrust laws to credentialing programs which provide information and advice, and has set forth in some detail his view of the appropriate first amendment analysis. See Kissam, supra note 47 , at 40-48; Kissam, supra note 41 , at 62-64. There are, of course, certain types of lobbying activities that may be directed toward the adoption of quality-of-care standards by governmental bodies (and perhaps even private standard setting groups) which are within the protection of the first amendment, see infra note 261, but like Professor Havighurst, I do not believe that reliance on the first amendment is necessary in most cases; the procompetitive effects of credentialing can be adequately recognized in more traditional antitrust terms. See Havighurst and King, supra note 11, at 194.

245. For example, one of the objections to "grandfathering" in credentialing, i.e., the practice of not requiring those already credentialed to conform to newly adopted standards, is that such standards no longer generate procompetitive information and may in fact deceive those who take the credentials as a representation of conformity with standards currently in effect. See Havighurst \& King, Private Credentialing of Health Care Personnel: An Antitrust Perspective (Part 2), 9 AM. J.L. \& MED. 263, 302 (1983).

246. See Havighurst \& King, supra note 11 , at $136,176$.

247. Id. at $133,155,176$.

248. For example, a trade association or certifying body comprised of competitors might adopt a set of product standards that eliminates virtually all forms of product differentiation, or removes 
effects felt by those outside the association; these outside effects are most likely simply the reaction of the market to information. Association membership and credentialing could be such a competitive advantage that those without them cannot effectively compete at all. There are circumstances where the outside effects felt through the exclusion of others might restrict output. The denial of credentials might be a vehicle to raise rivals' costs. ${ }^{249}$ The association's credentials might then be characterized as akin to an "essential facility."250 The presence of a significant number of competitors without them would suggest otherwise.

The itinerant surgery rule does not preclude surgical practice by non-ACS surgeons. Nor does it prevent ACS surgeons from referring patients to nonACS surgeons. JCAH hospital accreditation standards do not require that hospitals grant surgical privileges only to ACS fellows. Seemingly, decisions by hospitals, patients, and other providers to utilize ACS surgeons are based simply on the information value ACS credentials provide. Non-ACS surgeons are at a competitive disadvantage, but that alone does not establish adverse competitive effect. Unless the rule is sufficiently arbitrary to mislead consumers, or conveys no information that may be relevant to a significant number of them, the harm allegedly caused competing surgeons results simply from the reliance on accurate information, that is, that ACS fellows provide their own post-surgical care, and thus informs the competitive process. Non-ACS surgeons also are likely to lose referrals from ACS fellows, and other physicians as well. Rural hospitals may be disadvantaged in competing with metropolitan hospitals because patients desire surgery by ACS fellows, or because such fellows cannot perform surgery in these hospitals without delegating responsibility for post-operative care. But absent

from the market a variation of the product traditionally sold at a particularly low price (e.g., seconds). Such standardization might have significant direct price and output effects, or might facilitate tacit collusion or other interdependent behavior having such effects. See 7 P. Arex.d, supra note 48, at 373,386 (1986). In such cases, the focus is on the elimination of competition among those parties to the agreement, rather than upon the exclusion of third parties. This distinction between "inside" and "outside" effects underlies a number of recent cases reexamining boycott doctrine. See, e.g., Vogel v. American Soc'y of Appraisers, 744 F.2d 598, 600 (7th Cir. 1984).

249. See Heidt, supra note 148, at 1533-35, 1572. In some cases, the target may be a group of rivals whose costs and prices are lower than the defendants'. Their elimination, or an increase in their costs, may have adverse price and output effects, if such rivals are unable to duplicate the defendants' activity. Professor Heidt suggests that the AMA's actions against chiropractors at issue in Wilk may be explained on this basis. Id. at 1574 .

250. The essential facility doctrine is derived from United States v. Terminal R.R. Ass'n of St. Louis, 224 U.S. 383 (1912), a case dealing with a so-called bottleneck monopoly. While the doctrine is poorly defined, it is generally described as having the following elements: (1) control of an essential facility by a monopolist (or a group that collectively has monopoly power); (2) the denial to a competitor of access to the facility; (3) inability on the part of the competitor reasonably to duplicate the facility; and (4) the feasibility of access. MCI Communications Corp. v. AT\&T, 708 F.2d 1081, 1132-33 (7th Cir.), cert. denied, 464 U.S. 891 (1983). For an extended discussion, see Note, Unclogging the Bottleneck: A New Essential Facility Doctrine, 83 Colum. L. Rev. 441 (1983). The decision in Northwest Wholesale Stationers, Inc. v. Pacific Stationery \& Printing Co., 472 U.S. 284, 298 (1985), while not put in terms of the essential facility doctrine, uses some of its language in holding that the per se rule against boycotts should not be applied to expulsion from a buying cooperative absent a showing that defendants had market power "or unique access to a business element necessary for effective competition." 
evidence of some additional agreement between ACS and hospitals, these are informational harms.

The ban on itinerant surgery also has a direct effect on competition among ACS fellows. Each is precluded from competing with other surgeons (ACS or otherwise) by offering patients a choice as to post-operative care. ACS fellows are thus precluded from offering patients an alternative product which may, in some cases, be less costly. Competition between ACS fellows and nonsurgeons with respect to post-operative care is also eliminated as a result, a fact that may lead to the erroneous conclusion that this should be considered a per se illegal boycott.

The effect of the rule is to standardize the product offered by ACS surgeons. They provide only a surgery/post-operative care package. The decision not to compete among themselves in this respect is not simply an individual reaction to information. It results from agreement. But all credentialing necessarily involves some standardization; without it, credentialing would be meaningless. Physicians forgo an element of rivalry to obtain the benefits of credentials, as is true to a degree with any joint venture. Credentials are not severable. One cannot be an ACS fellow for one patient but not for another. If accreditation is procompetitive, and the specific rule in question bears a rational relationship to its informational function, limitations on rivalry that necessarily result must also be legitimate. The mere fact that the rule results in a refusal to utilize the services of others who might otherwise compete cannot determine the outcome.

Where consumers have no choice, as they might not if all surgeons were ACS fellows, the provision of information might be irrelevant, and the anticompetitive effects of the rule more severe. But choices apparently exist. A standard that clearly deceives, or bears no rational relationship to the informational and advice functions of credentialing, may be competitively unjustified. Finally, a credentialing standard that directly limits price competition or allocates markets among those who are members of the association cannot be viewed as procompetitive. These are the issues on which inquiry must focus.

The actions taken by the AMA against chiropractors may seem to bear a superficial resemblance to the ACS itinerant surgery rule. In each case, the rule under attack limited competition between members and alternative providers (surgeons and non-surgeons, physicians and chiropractors) by prohibiting members from dealing with them. But the chiropractor boycott is significantly different. The itinerant surgery rule precluded use of nonsurgeons only for post-operative care. It did not prevent referrals or other forms of collaboration, and did not result itself in any denial of facilities or services to non-surgeons. The AMA boycott went much further in all these respects. Even if there was some informational element in these actions, their effect went well beyond those resulting from information alone.

Moreover, membership in the AMA is not a credential that provides information in the sense specialty credentialing does. Unlike other 
credentialing, the non-affiliation rule provides little information about the qualifications, competence, or services of physicians. It is unlikely that consumers, physicians, or insurers rely on AMA membership to differentiate physicians from chiropractors. Avoidance of confusion between them might justify a refusal to admit chiropractors to AMA membership, but this was not at issue; chiropractors did not seek to be AMA members. Some consumers might want to know that physicians do not collaborate with chiropractors, but AMA membership is not likely to be taken as certification that particular physicans satisfy standards of this sort. In addition, the non-affiliation rule is so broad as to bear no rational relationship to any informational function performed by AMA membership. It effectively denied radiological and laboratory services, and sharing of research and clinical experiences, ${ }^{251}$ to chiropractors, matters which appear irrelevant to consumer choice. The rule also resulted in denial of access to hospital facilities. Even without the threat that accreditation will be revoked by JCAH, such facilities are likely to be denied because physicians on hospital staffs are bound not to collaborate with chiropractors. While this might be characterized as "non-verbal communication" of information, ${ }^{252}$ that is, a signal through denial of facilities that chiropractic is not a science, or is harmful, its effects are more than informational. The ability of consumers to make choices based upon all available information is impaired.

Finally, the AMA acted in conjunction with a number of other professional associations, which at the urging of the AMA adopted similar non-affiliation standards. ${ }^{253}$ This extended the adverse effects on chiropractic, and also assured that information and advice given consumers by the non-affiliation rule was uniform. The availability of competing information sources serves as a check on its accuracy and serves to enhance consumer choice. ${ }^{254}$ The agreements found in Wilk, however, eliminated competition among otherwise independent information sources.

The AMA non-affiliation rule and related actions cannot be justified on informational grounds. Nor can it be characterized as procompetitive because it enhances rivalry through protection of reputation for quality. Physicians do have a legitimate competitive interest in reputation. And particular physicians could well decide that their competitive stance would be damaged by

251. Whether a given hospital might deny chiropractors access to radiological facilities, and whether a particular group of radiologists might refuse to associate with chiropractors, are different questions. Radiologists (and hospitals) might increase their liability risks if they fail to take reasonable steps to assure proper treatment of diseases misdiagnosed by chiropractors but which they detect. The avoidance of such liability might justify a refusal of access. Compare Calvani \& James, Antitrust Law and the Practice of Medicine, 2 J. LEG. MEd. 75, 89 (1980), with Denying Hospital Privileges, supra note 6, at 1219, 1243; Health Professionals' Access to Hospitals, supra note 7, at 1191-95.

252. In Wilk, the AMA's economic expert advanced this argument, which was rejected as "speculative," particularly given the lack of evidence of any confusion between chiropractors and physicians in the eyes of the public. 671 F. Supp. at 1479.

253. See supra note 237.

254. See Havighurst \& King, supra note 245, at 264-66. In this study, the authors deal at length with the need to preserve a competitive market in the provision of information and opinion relating to health care. 
affiliation with chiropractors. But an agreement not to affiliate could be so justified only if a physician's ability to compete is impaired if other physicians affiliate with chiropractors. If such affiliation is harmful to reputation, however, affiliation by others would appear to enhance the competitive posture of those who reject it.

In sum, the itinerant surgery rule might be justified on informational grounds. It does not appear that the AMA actions with respect to chiropractic can be similarly justified.

\section{IV}

\section{Quality-of-Care Considerations in Other Cases}

This section will examine briefly, within the framework developed in Part II, the relevance of quality-of-care justifications advanced in a variety of other cases. The treatment here is intended simply to highlight these issues in the setting of conduct frequently subjected to antitrust attack.

\section{A. Agreements with Respect to Price}

A group of providers may agree on the price to be charged consumers for particular services, or on the levels of reimbursement to be demanded from insurers or from government payors such as Medicaid. ${ }^{255}$ In justification, they assert that higher prices are necessary to assure quality of patient care generally, or for particular classes of patients, such as the indigent. Competition over price or reimbursement rates that are too low will cause providers to cut corners, with a corresponding quality reduction. Care for the poor will decline, the argument goes, unless such care is cross-subsidized by higher prices for all others. These assertions are squarely contrary to Professional Engineers, ${ }^{256}$ and find no support in consumer welfare analysis. Such agreements are presumed to have adverse price and output effects. They provide neither significant efficiencies nor information that facilitates consumer choice. There is, in any event, no assurance that quality will increase.

Provider boycotts of private and public insurers who reduce or refuse to increase reimbursement rates present the same quality-of-care issues. ${ }^{257}$ When such boycotts are the means of implementing an underlying price agreement, they should be treated as price-fixing agreements and cannot be justified in quality-of-care terms.

Not all provider boycotts of insurers are in this category. Such boycotts may be an effort to bargain (or protest) over matters other than price, as was

255. See, e.g., United States v. North Dakota Hosp. Ass'n, 640 F. Supp. 1028 (D.N.D. 1986); Michigan State Medical Soc'y, 101 F.T.C. 191 (1983); Raup, supra note 10.

256. National Soc'y of Professional Eng'rs v. United States, 435 U.S. 679 (1978), discussed supra at text accompanying notes 42.47 .

257. See cases cited supra note 10. 
arguably the case in Indiana Federation of Dentists. ${ }^{258}$ Even in some cases where reimbursement is at issue, price and output effects may be unclear; while the boycott appears to be price-related, there may be no real underlying price agreement. Assuming that adverse effects are either proven or properly presumed, none of the procompetitive effects considered in consumer welfare analysis are present. Naked concerted refusals to deal provide neither efficiencies nor information to consumers that cannot be provided in a less restrictive way.

The collective refusal of providers to participate in insurance programs, even when based upon considerations of price, may raise serious questions under the Noerr-Pennington doctrine. ${ }^{259}$ These boycotts may be viewed as a political protest designed to pressure legislative or executive bodies to alter the insurance programs that they finance or administer (such as Medicaid) or over which they have regulatory authority. Providers will assert that they are simply lobbying. The Noerr issues do not relate directly to quality of care and are outside the scope of this study. ${ }^{260}$ But it should be noted that a boycott of insurers, either government or private, ${ }^{261}$ goes well beyond the collective submission of information and expression of views in the political process. The adverse effects are not the result of the reaction of government or the public to such views but flow directly from the boycott agreement. The invocation of Noerr in these circumstances requires that the boycott agreement be characterized as a form of protected, non-verbal communication, a considerable extension of the doctrine as generally applied. ${ }^{262}$

258. FTC v. Indiana Fed'n of Dentists, 476 U.S. 447 (1986). Price was only indirectly involved in the dentists' withholding of x-rays. While the dentists complained that they would not be fully reimbursed by insurers for services rendered, they did not attempt to negotiate rates or otherwise directly deal with price.

259. The Noer-Pennington doctrine exempts from the antitrust laws even political activity, even when engaged in for anticompetitive purposes, to influence legislative and other political officials to carry out acts with anticompetitive effects. United Mine Workers of Am. v. Pennington, 381 U.S. 657 (1965); Eastern R.R. Presidents Conference v. Noerr Motor Freight, Inc., 365 U.S. 127 (1961). The exemption, which is grounded in the first amendment, applies to efforts to influence not only legislators but administrative bodies as well, but it does not protect actions where this political end is a "sham" to disguise conduct directed towards competitors. California Motor Transport Co. v. Trucking Unlimited, 404 U.S. 508 (1972).

260. The applicability of Noerr-Pennington in this boycott setting is discussed in detail in Superior Court Trial Lawyers Ass'n, 856 F.2d 226, 241-50 (D.C. Cir. 1988), cert. granted, 109 S. Ct. 1741 (1989); United States v. North Dakota Hosp. Ass'n, 640 F. Supp. 1028, 1040-43 (D.N.D. 1986); Michigan State Medical Soc'y, 101 F.T.C. 191 (1983). In each of these cases, professional service providers sought without success to bring boycotts targeted at government reimbursers within NoerrPennington, although the court in Superior Court concluded that first amendment concerns were sufficient to require proof of market power.

261. Because Noer-Pennington protects actions to influence public officials, boycotts of private insurers would appear to fall outside the exemption. In Allied Tube \& Conduit Corp. v. Indian Head, Inc., $108 \mathrm{~S}$. Ct. 1931 (1988), the Court held that actions taken by firms to influence industry standard-setting bodies to adopt standards that imposed handicaps on their rivals did not fall within Noer-Pennington, in cases where the standards adopted are in turn relied upon by government agencies.

262. See, e.g., Superior Court Trial Lawyers Ass'n, 107 F.T.C. 510, 3 Trade Reg. Rep. (CCH) I 22,373, at 23, $457-58$ (1986), rev 'd and remanded, 856 F.2d 226 (D.C. Cir. 1988), cert. granted, 109 S. Ct. 1741 (1989). 


\section{B. The Collective Withholding of Information}

A single business enterprise may disclose or withhold information as it sees fit. But an agreement among competitors to withhold information relevant to buyers in making quality-of-care decisions may violate the Sherman Act. In Professional Engineers, ${ }^{263}$ an agreement not to quote prices was held unlawful. A collective refusal to furnish $\mathrm{x}$-rays to insurers was condemned in Indiana Federation of Dentists. ${ }^{264}$ Agreements not to advertise prices have been similarly treated. ${ }^{265}$ Under what circumstances, if any, might such agreements be justified on the ground that buyers are unable to evaluate the information withheld and are thus likely to be misled?

Suppose a group of hospitals agrees not to disclose information about mortality rates in each. The agreement produces no efficiencies. But the hospitals will contend that such information is inherently misleading, and that the prevention of such misinformation is procompetitive. They will invoke the tradition of self-regulation designed to prevent deception.

Each hospital may elect not to release mortality rate data, or to release it with any explanation it deems appropriate. But here each has given up its independent judgment. The perceived need for agreement suggests that such information is competitively significant. Each agrees in order to gain assurances that others will not release the data, recognizing that release by one will pressure others to respond. The argument advanced to justify withholding recognizes the competitive significance of the information.

Self-regulation directed toward deception is competitively legitimate. But the issue here is not whether an association may discipline members who utter untruths. Mortality data are not false. The argument rests instead on the proposition that an entire category of truthful information cannot be understood by buyers, even if accompanied by explanations of its meaning. Buyer judgment being unreliable, decisions about such data should be made by the hospitals themselves.

The proffered justification focuses on the lack of sophistication in individual consumers and ignores the relevance of such information to others in the marketplace. In many cases, consumers delegate decisions about hospital care to physicians or other providers who are more able to evaluate data of this sort. The information is also relevant to insurers, who are not likely to misjudge its significance. Even if the agreement contemplates the release of the data to these groups and denies it only to the public at large, the argument that there are categories of information that consumers are incapable of understanding is simply contrary to the premises underlying the competitive model, which assumes the competence of consumers to process available information. Professional Engineers, Indiana Federation of Dentists, and a

263. National Soc'y of Professional Eng'rs v. United States, 435 U.S. 679 (1978).

264. FTC v. Indiana Fed'n of Dentists, 476 U.S. 447 (1986).

265. See United States v. Gasoline Retailers Ass'n, 285 F.2d 688, 691 (7th Cir. 1961); Federal Prescription Serv., Inc. v. American Pharmaceutical Ass'n, 484 F. Supp. 1195, 1201 (D.D.C. 1980), aff'd in part, rev'd in part, 663 F.2d 253 (D.C. Cir.), cert. denied, 455 U.S. 928 (1982). 
number of first amendment commercial speech cases ${ }^{266}$ rest on this basic proposition. These cases do not entirely foreclose the possibility that the assumption-the consumer's capability of assimilating accurate informationmay be disproven on the record in a particular case. However, judicial skepticism of such claims is manifest, ${ }^{267}$ and it is hard to imagine such a case.

This skepticism is well-founded. The proposition that consumers are best served when full, accurate information is available is too basic to overcome lightly. The presence of competing sources of information, which agreements to withhold eliminate, assures the availability of information and enhances the likelihood that it is accurate. Moreover, by controlling information, providers may also exert a direct control over competition from "outsiders."'268 It cannot be assumed that providers act solely in the public interest. Finally, even in those cases where government has regulated the content or availability of information relevant to consumer choice, it has generally required more, not less. ${ }^{269}$ The tendency of truthful information to mislead has not been corrected by withholding it altogether.

\section{Staff Privileges and Access to Hospital Facilities}

For most health care providers, staff privileges or, in some cases, a more limited form of access to hospital facilities, are necessary for survival in the marketplace. Without such access, providers are unable to render some services economically and must refer patients to others. Patients may be lost. Others may elect not to use providers without hospital access. Because those already having staff privileges play a significant role in granting or denying such privileges to others, they could use the process to limit competition from alternative providers or other comparable providers. The interest of hospital administrators may conflict with that of physicians on the staff and provide some check on their ability to restrict competition. In a competitive world, while physicians may desire to limit the grant of staff privileges to competitors, hospital administrators may want more physicians on the staff in order to gain access to patients. ${ }^{270}$ This conflict, however, is easily exaggerated. Administrators cannot alienate a hospital's medical staff to the point where staff physicians place their patients elsewhere or go elsewhere themselves. And administrators and staff providers share a number of other concerns. It is sometimes said that hospital administrators are primarily driven by concerns over costs, while staff providers are interested in quality

266. See, e.g., Bates v. State Bar of Ariz., 433 U.S. 350 (1977) (price advertising by lawyers); Virginia State Bd. of Pharmacy v. Virginia Citizens Consumer Council, Inc., 425 U.S. 748 (1976) (price advertising by pharmacists).

267. See, e.g., FTC v. Indiana Fed'n of Dentists, 476 U.S. 447, 462 (1986) ("even if the desired information were in fact completely useless to the insurers and their patients in making an informed choice ... the Federation would still not be justified in deciding on behalf of its members' customers that they did not need the information").

268. See Havighurst \& King, supra note 245, at 276.

269. See, e.g., The Truth in Lending Act, 15 U.S.C. $\$ \$ 1601$ et. seq. (1982).

270. See Denying Hospital Privileges, supra note 6, at 1219, 1223 and studies cited therein. 
no matter what the cost. ${ }^{271}$ There is some truth in this observation, but it is an oversimplification. In some cases, increases in efficiency within the hospital also increase the efficiency of those who work within it. There is also a substantial degree of shared interest in quality of care. Hospitals compete with other hospitals (and some other forms of provider organizations) in significant part on the basis of reputation for quality. ${ }^{272}$ Staff providers share this interest. Poor quality within the hospital has an associational effect on their own reputations. Patients may be lost if they fear admission or treatment in a hospital whose reputation is inferior to others. In terms of shared interests, a hospital is a loose form of joint venture in which conflicts are also present. ${ }^{273}$

A pattern of denials of staff privileges, or a policy that requires denials to a significant number of competitors, may provide a basis for inferring adverse competitive effects, at least where alternatives at comparable cost are not available to those denied. Denial of staff privileges to a single provider will seldom have such effects, as already noted. ${ }^{274}$ Even if the practice of this provider is curtailed or eliminated, it is unlikely that this alone will have a significant market impact. Assuming, however, that significant adverse effects are likely, denial of staff privileges to physicians or others with records reflecting incompetence or the likelihood of disruption of the hospital's operations is justified in terms of reputation and/or efficiency. Demonstrated incompetence increases legal liability costs and has adverse reputational effects on both the hospital and its staff. Disruption of the staff increases hospital costs and decreases the efficiency of particular providers on the staff. Courts are capable of making determinations of this sort without resolving broad quality-of-care disputes. ${ }^{275}$

Denial of staff privileges to whole groups of competitors or potential competitors poses more difficult issues. Because larger numbers of competitors are involved, substantial adverse effects are more likely. A hospital might, for example, follow a policy of granting surgical privileges only to fellows of the American College of Surgeons. The exclusion of nonfellows might in a given case eliminate a large number of surgeons from the market. On the face of it, this effect flows from the hospital's reliance on the informational effect of ACS credentials. Moreover, such a policy may enhance the hospital's reputation for quality in the eyes of consumers, who themselves

271. Id.

272. See supra text at notes 127-29.

273. See Blumstein \& Sloan, supra note 6, at 7; Kissam, Webber, Bigus \& Holzgraefe, supra note 6, at 609-11. The joint venture analogy is apt for the typical hospital in which the medical staff consists of individual, profit-maximizing providers who are not simply employees of the hospital.

274. See supra text at notes 130-38.

275. It should be noted that in some cases termination of staff privileges of individual physicians pursuant to state peer-review legislation may be within the state action exemption from the antitrust laws. See supra note 121. The 1986 Health Care Quality Improvement Act, Pub. L. No. 99-660, 100 Stat. 3784, also contains a limited antitrust exemption for physicians engaged in certain types of peer review, as defined by the Act. The reach of the Act is not yet clear. For a full discussion see Blumstein \& Sloan, supra note 6 , at 7, 32-33, 82-88. 
give weight to such credentials. Assuming that the provision of such information is procompetitive, the hospital's use of it in this fashion seems unobjectionable. The hospital's action also protects ACS fellows on its staff from some degree of outside competition and may reflect an agreement among them rather than an independent use by the hospitals of the information such credentials convey. Given this danger, the process by which the decision to rely solely on ACS credentials was made must be examined. ${ }^{276}$

Where non-physician health care providers, such as chiropractors, podiatrists, and nurse-midwives, are denied access to hospitals, the effects and justifications offered are different. ${ }^{277}$ Each of these groups provide services that compete within a particular range of services with established physician providers. The need for hospital access varies with each group. In most instances, these needs can be satisfied with something less than full staff privileges, which may not even be sought. ${ }^{278}$

Consumers may prefer to use the services of such alternative providers for a variety of personal reasons. Their presence in the market is often the result of such consumer choice, which may be frustrated by hospital conduct that keeps such providers from delivering services consumers desire. Moreover, these alternative providers often price lower than their physician competitors; their elimination from the market may therefore have direct price effects. ${ }^{279}$ Finally, denial of hospital access to such groups may retard innovation and development of different approaches to health care that question the established learning of physicians. ${ }^{280}$ In a given case, some or all of these adverse effects may be present and significant.

Invariably, denial of access to these alternative providers is explained as a measure to protect the public from inferior care, an explanation which in this broad sense is not cognizable in an antitrust case. But these cases do raise significant efficiency and reputational issues. First, in some circumstances the presence of such alternative providers on the hospital staff might increase the hospital's risk of legal liability and thus increase its costs. But this risk may be

276. I am assuming here that there is a substantial basis for believing that the hospital's action is otherwise likely to have adverse competitive effects. Whether this is so will require consideration of the power of the hospital and ACS surgeons in the market, and the alternatives available to non-ACS surgeons. If the hospital's action is likely to have such effects, the hospital should be required to establish that its decision was based upon the information conveyed by the credentials and that it was in the economic interest of the hospital as a whole to do so. If, for example, the hospital's action is induced by a market-wide agreement among ACS surgeons not to serve on the staff of any hospital extending privileges to non-ACS surgeons, its decision does not rest solely on the information ACS credentials convey.

277. These differences are examined in greater detail in Denying Hospital Privileges, supra note 6, at 1219, 1237-47. See also Kissam, supra note 130, at 1212-16; Health Professionals' Access to Hospitals, supra note 7 , at $1161,1185-98$.

278. In Wilk v. American Medical Ass'n, 719 F.2d 207 (7th Cir. 1983), cert. denied, 467 U.S. 1210 (1984), for example, chiropractors complained only of denial of access to hospital laboratory services and radiology facilities. Nurse-anesthetists have sought only the privilege of providing services in hospital operating rooms. Bhan v. NME Hosps., Inc., 669 F. Supp. 998 (E.D. Cal. 1987).

279. See Denying Hospital Privileges, supra note 6, at $1219,1246-47$ and studies cited therein.

280. Id. at 1247 . 
minimized if only limited privileges or access are allowed. ${ }^{281}$ Moreover, the assumption that alternative providers are more likely to engage in malpractice is questionable. ${ }^{282}$ Second, the hospital might incur higher costs in screening and supervising alternative care providers. Again, however, whether this is the case may depend on the relationship with the hospital being sought. Third, a grant of staff privileges to groups like nurse-midwives or chiropractors might cause injury to the quality reputation of the hospital and its staff. Whether this is so will depend on the nature of the alternative care group at issue (and how they are generally perceived) and on the form of hospital affiliation they desire.

The quality-of-care focus in these cases should be on these efficiency and reputational issues. Increased costs and adverse reputational effects cannot simply be assumed. They will vary among alternative provider groups and with the type of relationship at issue. Finally, where these efficiencies or other procompetitive justifications for the exclusion of such alternative care providers can be achieved in a reasonable, less restrictive way, the justifications should be rejected. As noted, the hospital's legitimate needs may be met by granting limited privileges or access to facilities without a grant of full staff privileges. Application of competence or credentialing standards to those within the provider group may be sufficient. Given the adverse effects that such group exclusions may cause, consideration of such alternatives as part of the antitrust analysis is warranted.

\section{Conclusion}

There is no single quality-of-care defense in health care antitrust cases. To the extent such a defense might be predicated on a balancing of social gains against adverse price and output effects, it is inconsistent with the focus on competitive effects which is central in antitrust analysis. Nor can such a defense be based on a dominant laudable purpose. Intent is relevant only as a predictor of effect. Where effect is established, intent is no longer of consequence.

Conduct that promotes efficiency, ameliorates the effects of market failures or imperfections, or increases quality rivalry among providers is, to this extent, procompetitive and may improve quality of care by enhancing the competitive process. Any further accommodation of quality-of-care concerns is a direct challenge to the central role of the market in the determination of quality, and therefore to the relevance of antitrust itself. It is for legislatures, not courts, to grant antitrust exemptions or otherwise displace the application of the antitrust laws.

281. In such cases, the availability of limited privileges or other narrowly defined relationships may be a reasonably less restrictive alternative to the same end, permitting the hospital to deal with the risk of increased liability without allowing the hospital to justify total non-affiliation.

282. See Denying Hospital Privileges, supra note 6, at 1242. 